\title{
Essential Oils in Livestock: From Health to Food Quality
}

\author{
Ralph Nehme ${ }^{1,2}$, Sonia Andrés ${ }^{3}$, Renato B. Pereira ${ }^{4}\left(\mathbb{D}\right.$, Meriem Ben Jemaa ${ }^{5}$, Said Bouhallab ${ }^{2}$, \\ Fabrizio Ceciliani ${ }^{6}$ (D), Secundino López ${ }^{3,7} \mathbb{D D}^{\text {, Fatma Zohra Rahali }}{ }^{5}$, Riadh Ksouri ${ }^{5}$, David M. Pereira ${ }^{4}$ \\ and Latifa Abdennebi-Najar 1,8,*(D)
}

1 Quality and Health Department, IDELE Institute, 149 rue de Bercy, 75595 Paris CEDEX 12, France; ralph.nehme@idele.fr

2 INRAE, Institut Agro, STLO, F-35042 Rennes, France; said.bouhallab@inrae.fr

3 Instituto de Ganadería de Montaña (CSIC-Universidad de León, Finca Marzanas s/n, 24346 Grulleros, Spain; sonia.andres@eae.csic.es (S.A.); s.lopez@unileon.es (S.L.)

4 REQUIMTE/LAQV Laboratory of Pharmacognosy, Department of Chemistry Faculty of Pharmacy, University of Porto R Jorge Viterbo Ferreir 228, 4050-313 Porto, Portugal; rjpereira@ff.up.pt (R.B.P.); dpereira@ff.up.pt (D.M.P.)

5 Laboratory of Aromatic and Medicinal Plants, Biotechnology Center of Borj-Cédria, Hammam-Lif BP 901 2050, Tunisia; mariembenjemaa@yahoo.fr (M.B.J.); fatma1707@gmail.com (F.Z.R.); ksouririadh@gmail.com (R.K.)

6 Department of Veterinary Medicine Università degli Studi di Milano, 20122 Milano, Italy; Fabrizio.ceciliani@unimi.it

7 Departamento de Producción Animal, Universidad de León, 24007 León, Spain

8 Centre de Recherche Saint-Antoine (CRSA), Sorbonne University, INSERM UMR_S_938, 75020 Paris, France

* Correspondence: Latifa.najar@idele.fr; Tel.: +33-(0)1-40-04-51-64; Fax: +33-(0)-1-40-04-49-60

Citation: Nehme, R.; Andrés, S.; Pereira, R.B.; Ben Jemaa, M.; Bouhallab, S.; Ceciliani, F.; López, S.; Rahali, F.Z.; Ksouri, R.; Pereira, D.M.; et al. Essential Oils in Livestock: From Health to Food Quality. Antioxidants 2021, 10, 330. https:// doi.org/10.3390/antiox10020330

Academic Editor: Ana I. Rey

Received: 31 January 2021

Accepted: 20 February 2021

Published: 23 February 2021

Publisher's Note: MDPI stays neutral with regard to jurisdictional claims in published maps and institutional affiliations.

Copyright: (C) 2021 by the authors Licensee MDPI, Basel, Switzerland. This article is an open access article distributed under the terms and conditions of the Creative Commons Attribution (CC BY) license (https:/ / creativecommons.org/licenses/by/ $4.0 /)$.

\begin{abstract}
Using plant essential oils (EOs) contributes to the growing number of natural plants' applications in livestock. Scientific data supporting the efficacy of EOs as anti-inflammatory, antibacterial and antioxidant molecules accumulates over time; however, the cumulative evidence is not always sufficient. EOs antioxidant properties have been investigated mainly from human perspectives. Still, so far, our review is the first to combine the beneficial supporting properties of EOs in a One Health approach and as an animal product quality enhancer, opening new possibilities for their utilization in the livestock and nutrition sectors. We aim to compile the currently available data on the main anti-inflammatory effects of EOs, whether encapsulated or not, with a focus on mammary gland inflammation. We will also review the EOs' antioxidant activities when given in the diet or as a food preservative to counteract oxidative stress. We emphasize EOs' in vitro and in vivo ruminal microbiota and mechanisms of action to promote animal health and performance. Given the concept of DOHaD (Developmental Origin of Health and Diseases), supplementing animals with EOs in early life opens new perspectives in the nutrition sector. However, effective evaluation of the significant safety components is required before extending their use to livestock and veterinary medicine.
\end{abstract}

Keywords: essential oils; antioxidant; antimicrobial; livestock; encapsulation; inflammation; mastitis; immunity; fermentation; nutrition

\section{Introduction}

The intensification of animal husbandry and the globalization of trade have contributed to the extensive and improper use of antibiotics to combat infectious diseases. Since the end of the 1990s, awareness of this risk increased, prompting a gradual mobilization of the international community [1]. It has become an important issue as it has been recognized as a selective pressure, driving the accelerated emergence of bacterial resistance worldwide [2,3]. Prudent use of antibiotics in the future is urgently needed. It should be addressed in a One Health perspective, given that antibiotic resistance in humans, food, environment, and animals are connected, and exchange may continuously occur $[4,5]$. 
In 2006, the European Union banned all antibiotics as animal growth promoters and proposed alternatives [6]. Natural products, such as medicinal plants, essential oils (EOs), and herbal extracts, are regarded as promising alternative agents [7]. EOs are among the most economically relevant plant-derived products, being frequently responsible for several species' health-promoting properties. These compounds are extracted from several plants generally localized in temperate to warm countries, like the Mediterranean and tropical countries, representing an important part of the traditional pharmacopoeia. EOs are a mixture of low-molecular-weight molecules that include terpenes (monoterpenes and sesquiterpenes), alcohols, aldehydes, and ketones which, in addition to their bioactive molecules, are also responsible for the aromatic fragrance that these materials frequently exhibit [8]. Presently, over 3000 EOs are known, $10 \%$ of which are commercially and economically relevant. These products are potential reservoirs of many bioactive compounds with several beneficial properties, and are aligned with current consumer preference for natural products [9]. They also offer the advantage of being better tolerated in the human body with fewer side effects [10].

EOs were also exploited for their flavoring properties [11,12] and for their potential to be used as food preservatives as they extend the length of the shelf life of products [13] or reduce the concentration of Clostridium numbers [14]. However, the main obstacle to using them as food preservatives is that they are often not potent enough and cause organoleptic alteration when added in sufficient quantities to induce the antimicrobial effect. However, this approach requires more insights into the interaction between molecules to determine the most synergetic effects, which remain elusive.

The popularity of EOs in the animal field and health has increased rapidly during the last decade. Nevertheless, their antioxidant and beneficial immunomodulatory effects in the ruminant sector remain poorly explored $[15,16]$. Mostly in poultry and pig sectors, studies have highlighted the capacity of some EOs to increase animal performances and efficiency by enhancing digestive secretions [17], increasing the number of probiotic bacteria such as Lactobacillus spp. [18,19], stimulating the immune function and the gastrointestinal microbiota [20,21], and decreasing oxidative stress [20]. However, some inconsistencies regarding the efficacy of EOs still exist, mainly linked to the nature of the compounds and some intrinsic and extrinsic factors, such as infection, nutritional status, environment, and particularly, diet composition [22].

The potential use of EOs as new nutraceutical additives during early growth (pregnancy and/or lactation) has not been explored yet and might be a very promising way to limit the use of antimicrobials in livestock, according to the DOHaD (Developmental Origin of Health and Diseases) concept. This concept was initially developed in humans by Barker $[23,24]$ and was extended more recently to animal science $[25,26]$. This plan may raise early animals in an antibiotic-free production environment and drive heard performances and efficiency at later life, contributing to reduce antimicrobial resistance.

To our knowledge, little is known about the potential use of EOs in livestock. The literature's significant findings are related to medicinal plant species' effects among livestock disease without distinguishing the effects of their isolated bioactive compounds. Data on EOs in ruminant and particularly the dairy sector are also limited. Our review is the first to overview the current knowledge about the antioxidant and antimicrobial properties of EOs in both monogastric and ruminant husbandry, to treat mastitis, and use as feed additives, modulation of rumen metabolism, and in animal product-derived foods. Its finality is to drive the nutritional and pharmaceutical industries to the potential use of EOs to improve animal health and explore encapsulated EOs as enhancers of milk and meat quality products that can facilitate their implementation as natural preservatives in foods.

\section{Methods}

To cover a maximum range of publications from Scopus, Web of Science (WOS), and Google scholar, we screened for the different database terms "essential oils", "antibacterial", "anti-inflammatory", "immunity, "additive", "diet", "animal products", "livestock", 
"encapsulation", and in some cases, combining the primary taxonomic designation and botanical synonym names of plants with the listed key terms. Then, we performed an additional literature search from WOS on EOs in livestock. The total number of articles treating the use of EOs linked with animal production and livestock and their abstract between 2010 and 2021 was 919 . The distribution of the number of papers according to the year of publication (2010-2021) is represented in Figure 1.

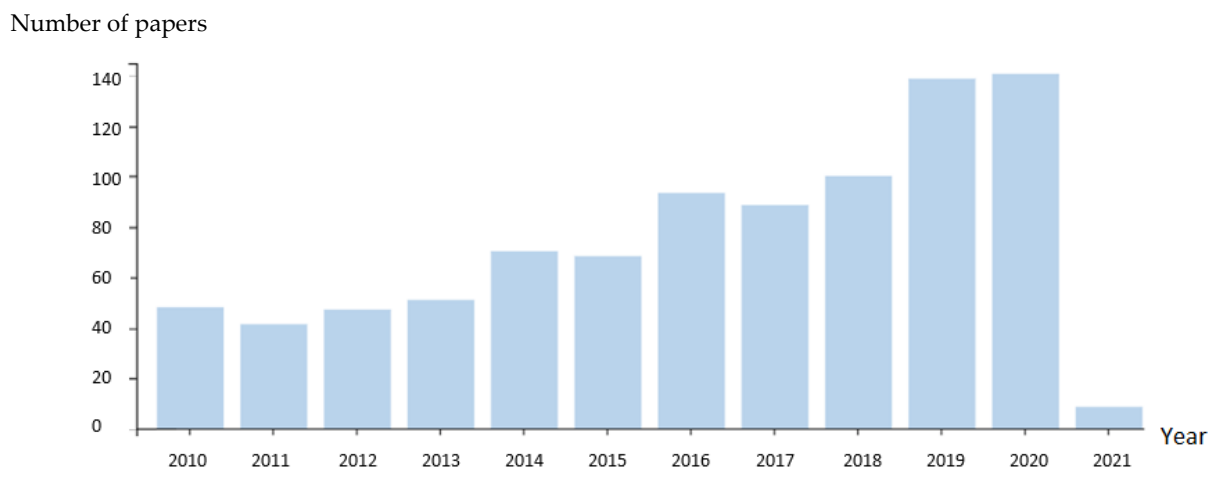

Figure 1. Distribution graph of the number of the articles containing essential oils (EOs) and a livestock animal or an animal food product according to the year of publication (2010-2021).

Among these articles, 138 records were obtained related to the characteristics of EOs as an anti-inflammatory, antibacterial, and immunoregulator, and 28 papers linking the use of EOs to treat mastitis, which is a new field of research.

Figure 2 shows an "Epic epoch" graph allowing to visualize the first 5 most used keywords in each article for each year and their evolutions. The map presents the different fields where EOs were used. We notice the growing evolution of the terms "chicken" and "storage" and the decreasing evolution of the word "diet".

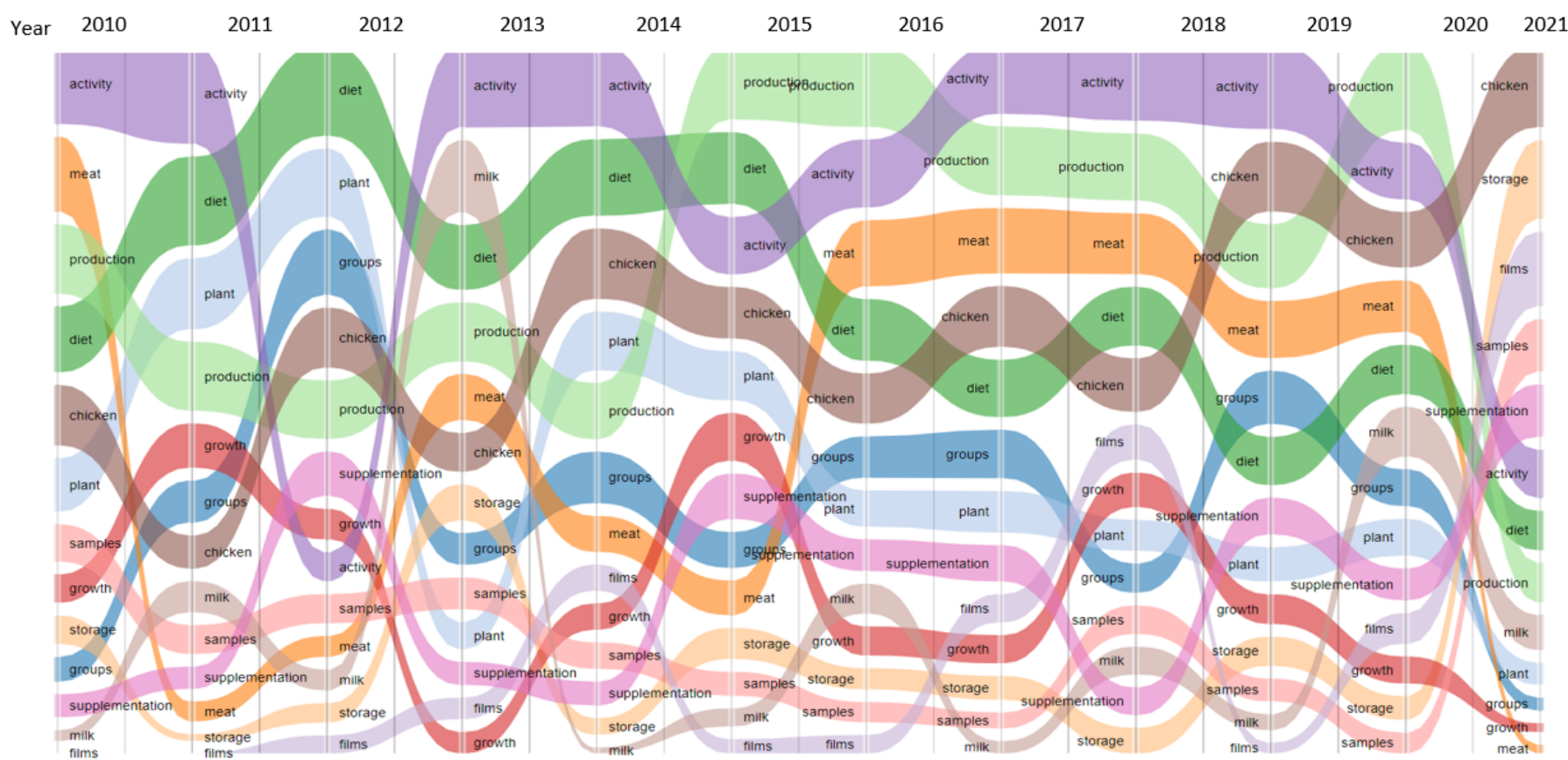

Figure 2. "Epic epoch" graph allowing to visualize the first 5 most used keywords in each article for each year, from 2010 to 2021. 
Additional literature screening was performed to compare the number of articles with EOs in both monogastric and ruminants. When utilizing the keyword "EO" AND ("milk OR cow OR dairy OR cattle OR ruminant OR rumen OR sheep OR goat"), we obtained 478 articles between 2010 to 2021, with 15 reports in 2010, reaching a maximum of 80 papers in 2020. In non-ruminants, when screening with "EOs" AND ("pork OR pig OR swine OR chicken OR poultry OR monogastric"), we obtained 666 results with 40 articles in 2010 versus 110 in 2020. Note that the number of articles related to "EO" AND "in vitro" studies in livestock animal was 118, while only 15 papers were related to in vivo studies.

\section{Importance of EOs}

EOs are known for their natural protecting role for the host plants and the fact that these oils contain properties many times more powerful than those found in dried herbs. Among these properties are the antibacterial, antimicrobial, antiviral, and antifungal activities, together with some particular medicinal effects that make EOs of very considerable interest $[27,28]$.

\subsection{Definition of EOs}

EOs, also called volatile or ethereal oils [29], are aromatic lipophilic liquids obtained from plant material (flowers, buds, seeds, leaves, twigs, bark, herbs, wood, fruits, and roots). They can be obtained by expression, fermentation, enfleurage, or extraction, but steam distillation is most commonly used for commercial production of EOs [30]. The term 'essential oil' is thought to derive from the name coined in the 16th century by the Swiss reformer of medicine, Paracelsus von Hohenheim, who named the effective component of a drug Quinta essential [29]. As mentioned above, an estimated 3000 EOs are known, of which about 300 are commercially important destined chiefly for the flavors and fragrances market [30]. It has long been recognized that some EOs have antimicrobial properties [29], and these have been reviewed in the past [31,32], like antimicrobial properties of spices [31]. Still, the relatively recent enhancement of interest in 'green' consumerism has renewed scientific interest in these compounds [32,33]. Besides antibacterial properties [32,34,35], EOs or their components have been shown to exhibit antiviral, antimycotic [34], anti-toxigenic [35,36], antiparasitic [37,38], and insecticidal properties [39,40]. These characteristics are possibly related to these compounds' function in plants [29,41].

\subsection{Historical Use of EOs}

Although spices were used for their perfume, flavor, and food preservatives since antiquity [42], only turpentine oil was mentioned in Greek and Roman history [29].

Concerning EO extraction, distillation was the first used method in the East (Egypt, India, and Persia) [29] more than 2000 years ago, and was improved in the 9th century by the Arabs [42].

The Catalan physician Villanova (ca. 1235-1311) wrote the first authentic EO distillation account [29]. It was only by the 13th century that pharmacies made EOs and pharmacopoeias described their pharmacological effects [42]. Still, EO's utilization was not widespread in Europe before the 16th century via their trade in London City [43]. In that century, Brunschwig and Reiff, Strassburg physicians, mentioned, in each of their publications on EO distillation and use, only a few oils: anise, cinnamon, clove, juniper wood, mace, nutmeg, rosemary, spike, and turpentine [29]. The tea tree oil used for medical purposes has been recorded since Australia's colonization at the end of the 18th century [44]. The first experimental measurement of EO antimicrobial efficiencies was performed in 1881 by De la Croix [24].

\subsection{Current Use of EOs}

Presently, EOs are used in various fields. The pharmaceutical, cosmetic, and food industries are increasingly interested in EOs due to their biological activities, notably antibacterial, antifungal, and antioxidant ones. For example, in the European Union (EU), 
EOs are the most used in food as flavoring agents, in cosmetics such as aftershaves and perfumes, and in pharmaceuticals for their attractive functional efficiencies [45]. Moreover, the pure molecules of EOs have been used as food flavorings [46], as dental care products [47], as antiseptics [48,49], and as feed supplements for livestock [50,51].

Natural preservatives based on EOs have become commercially available, such as 'DMC Base Natural'. This food preservative (produced by DOMCA S.A., Alhendı'n, Granada, Spain) is composed of 50\% EO mixture (rosemary, sage, and citrus) and 50\% glycerol [52]. Another example of commercialized EOs is 'Protecta I' and 'Protecta II', consisting of blended herb extracts proposed by Bavaria Corp. Apopka, FL, USA. The contained EOs are dispersed in sodium citrate and sodium chloride solutions [53].

\section{Extraction Methods for EOs}

Extraction is the main factor that ensures the quality of Eos, and inappropriate extraction methods can cause losses in volatile compounds and decrease the quality of obtained extracts. There are two main categories of EOs' extraction procedures: conventional and unconventional or innovative methods.

\subsection{Conventional Extraction Methods}

In this category of extraction techniques, the heating process' water distillation is classically used to obtain EOs from aromatic plants by two methods: hydro distillation and steam distillation. As for the first method, plant material is immersed into boiled water inside the alembic and vapors are condensed onto liquid in a decanter separating the EO from water. In contrast, in the steam distillation, plant material is heated by water steam. Another method used to recover EO compounds is solvent extraction by using acetone, petroleum ether, hexane, methanol, or ethanol, but the inconvenience of this method is that it allows extracting other non-volatile compounds at the same time which makes the second step of EO purification essential [54].

\subsection{Innovative Extraction Methods}

New EO extraction techniques have emerged with many advantages in recent years, such as reducing extraction time, energy consumption, and solvents used and carbon dioxide emission [55]. Among these innovative techniques is solvent-free microwave extraction (SFME), a combination of heating plant samples using microwave energy followed by dry distillation at atmospheric pressure in the absence of any solvent. This method's advantages are to obtain EOs with high yield and selectivity, shorter extraction time, and a green and safe process [56]. Another emerging method is supercritical fluid extraction using fluids at critical temperature $(\mathrm{Tc})$ and pressure $\left(\mathrm{Pc}_{\mathrm{C}}\right.$, having remarkable properties such as low viscosity, high diffusivity, and density closer to liquids [55]. Generally, for extracting EO compounds, carbon dioxide fluid is used, and the obtained extract is not pure and further purification stages are needed. Also, water use at subcritical state is a powerful method for extracting EOs [57]. The subcritical water stage is reached when water pressure becomes higher than the critical pressure and temperature lower than the critical temperature, or vice-versa. This extraction method is considered the best alternative EO recovery technique since it enables a fast isolation process at a low working temperature [58].

\section{Chemical Composition of EOs}

The composition of EOs from a particular species of plant can differ depending on harvesting seasons, genetics, agricultural practices, and geographical sources [59-61]. Such variation led to the formation of chemically different molecules, but with similarities. For example, in Greek oregano plants, the sum of cymene, $\gamma$-terpinene, carvacrol, and thymol is similar in EO derived from different geographic origins [62]. Also, it remains stable whatever the season of plant harvesting $[63,64]$. This indicates that the four listed compounds are biologically and functionally associated. 
Adding fertilizers containing potassium nitrogen and phosphorous could increase the amount of EOs and change its composition. Fertilizers could increase the concentration of some enzymes responsible for the biosynthesis of terpenoids [61]. Sarmoun et al. showed that irrigation could affect the quality of EOs produced by Rosmarinus officinalis L.: the non-irrigated plant has a higher yield of EOs than the irrigated plant. However, the EOs, made from the irrigated Rosmarinus officinalis, show more variability in their compounds than the non-irrigated plant, such as trans-verbanol and linalyl-isobutyrate [65].

Generally, EOs produced from herbs harvested during or immediately after flowering possess the most potent antimicrobial activity [66]. Enantiomers of EO components have been shown to exhibit antimicrobial activity to different extents [67]. Table 1 shows the significant components of selected EOs that exhibit antibacterial properties.

Table 1. Major components of selected essential oils (EOs) that exhibit antibacterial properties.

\begin{tabular}{cccc}
\hline Latin Name of Plant Source & Major Components & Approximate \% Composition & References \\
\hline & & & \\
\\
\end{tabular}

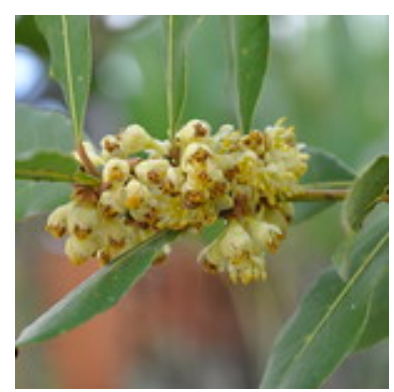

Laurus nobilis Credit: Stefano

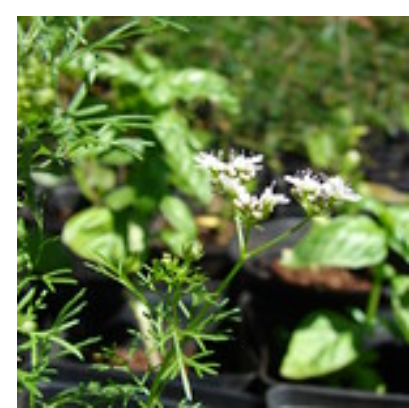

Coriandrum sativum Credit: Forest \& Kim Starr

$\begin{array}{cc}1,8 \text {-Cineol } & 51.63-63.19 \% \\ \text { Borneol } & 5.8-12.80 \%\end{array}$

$51.63-63.19 \%$
$5.8-12.80 \%$

[69]
$40-70 \%$

$[70,71]$ 
Table 1. Cont.

\begin{tabular}{|c|c|c|c|}
\hline Latin Name of Plant Source & Major Components & Approximate \% Composition & References \\
\hline & $\begin{array}{c}\alpha \text {-Pinene } \\
\text { Bornyl acetate } \\
\text { Camphor } \\
\text { 1,8-Cineole }\end{array}$ & $\begin{array}{l}2-25 \% \\
0-17 \% \\
2-14 \% \\
3-89 \%\end{array}$ & [72-74] \\
\hline $\begin{array}{l}\text { Rosmarinus officinalis } \\
\text { Credit: Peter Stenzel }\end{array}$ & & & \\
\hline
\end{tabular}

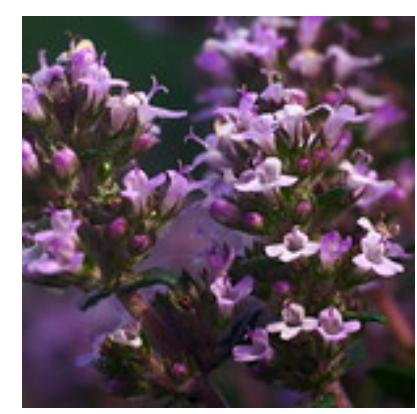

$$
\text { 2-17\% }
$$

$\begin{array}{cc}\text { Thymol } & 10-64 \% \\ \text { Carvacrol } & 76.1 \% \\ \text { ס-Terpinene } & 2-31 \% \\ \text { p-Cymene } & 10-56 \%\end{array}$

Thymus vulgaris

Credit: Ralf Wimmer

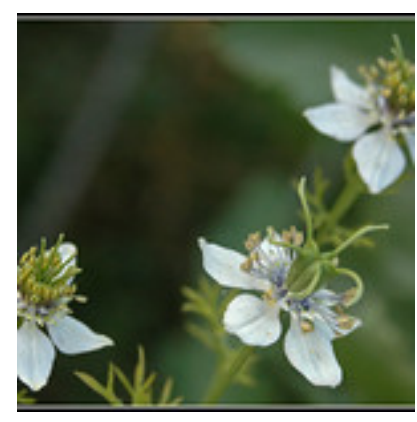

Nigella sativa

Credit: Eran Finkle

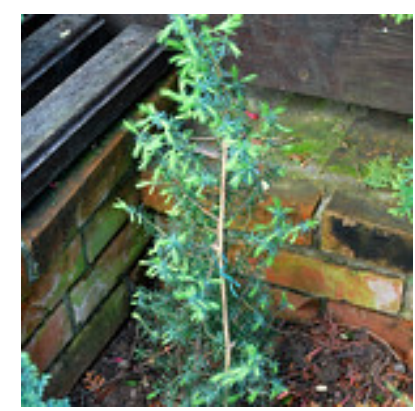
Thymoquinone
Carvacrol
$p$-Cymene

$27-45 \%$

$7-11.6 \%$

$7-15 \%$

[76]

Juniperus officinalis

Credit: Zoran Radosavljevic

$\begin{array}{cc}\text { B-Phellandrene } & 4.9-23.8 \% \\ \alpha \text {-Terpinyl acetate } & 4.6-15.5 \% \\ \alpha \text {-Pinene } & 28-60 \% \\ \alpha \text {-Phellandreneinene } & 0.8-17.7 \% \\ \text { Manonyl oxide } & 0.4-14.4 \%\end{array}$


Table 1. Cont.

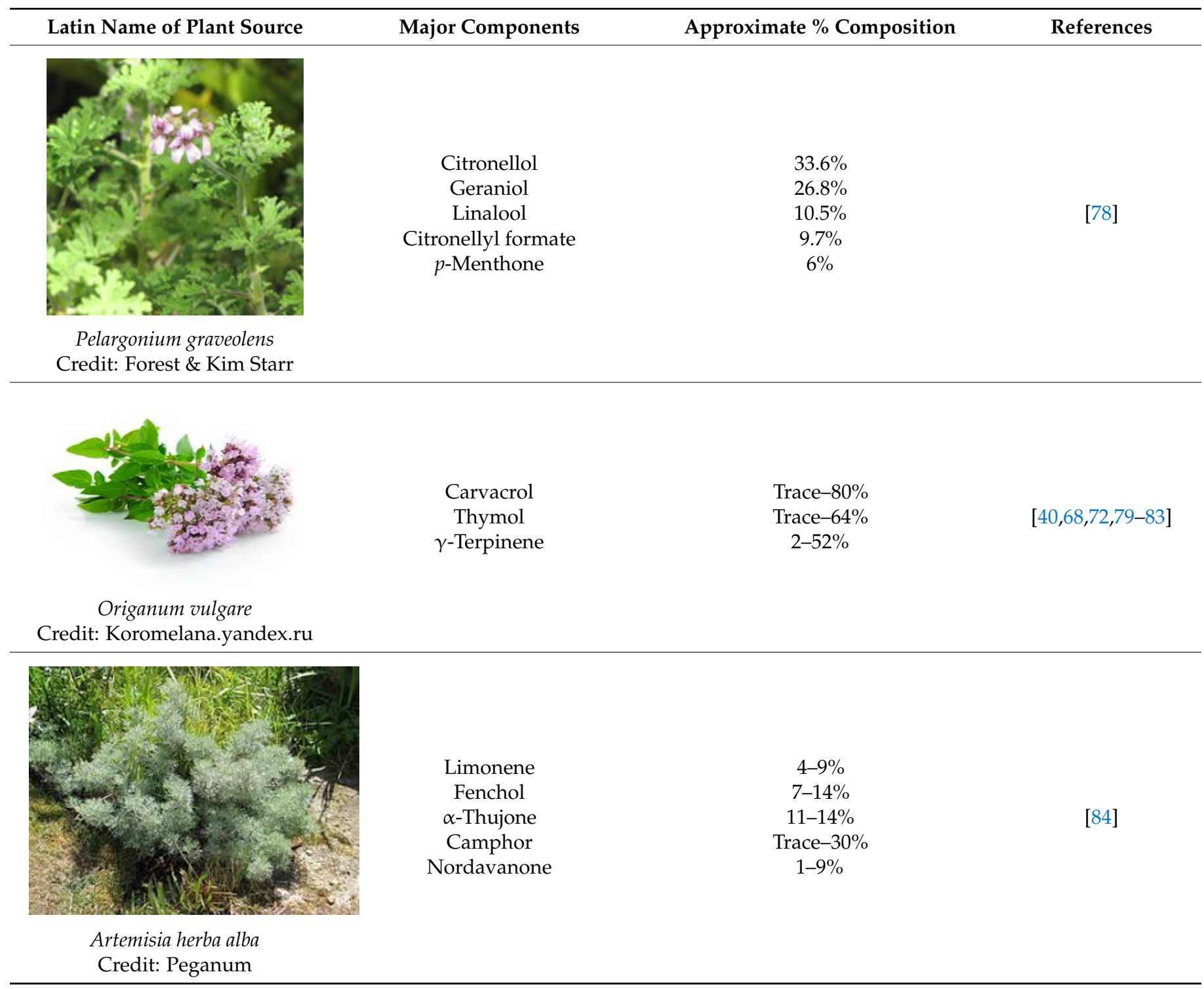

\section{Stability and Encapsulation of EOs}

Although EOs are considered secondary and non-essential plant metabolites, they have gained interest around the world due to their specific biological functions [61], many of which lend themselves to commercial exploitation. EOs production on a larger scale was started in the USA in the earlier 19th century [85]. Indeed, combining their established historical use as medicines to their range of biological activities aroused a great interest in their use as medicinal products [63]. Besides, attractive EOs, which leave a pleasant memory association, are used as marketing devices to sell cosmetic products, including detergents, scent perfumes, lotions, soaps, and household cleaners [86]. For instance, lavender EO and d-limonene from the citrus peel are potent solvents, and they are used in a wide variety of cleaning and cosmetic products [85]. For food industries, EOs are more and more considered to act as natural additives as antioxidant/antimicrobial agents [87]. The remarkable efficiency of most EOs against a wide range of pathogenic microorganisms, responsible for food spoilage and generally involved in food poisoning, was repeatedly reported [86-88].

However, it has been repeatedly discussed that EOs' valorization in innovative industries is not economically and practically ideal $[89,90]$. One of the crucial issues with using EOs as green and efficient bioactive molecules is their impact on the final product's sensory 
properties. The EO required to inhibit microbial growth may compromise organoleptic properties (aroma and taste) and produce an undesirable effect [91]. Alternatively, the use of lower concentrations of EOs may be possible if multiple preservation strategies that result in additive or synergistic effects on antimicrobial activity are involved [90,92].

Besides, it was confirmed that the incorporation of EOs in foods can be prejudice given their hydrophobicity and volatility [89]. Thus, EOs lose small quantities of volatile compounds when stored at high temperatures. Some components are highly unstable at $\mathrm{pH}$ variations, like citral, easily decomposed in an acidic environment [93]. Moreover, the hydrophobicity of EOs leads to their heterogeneous distribution in an aqueous medium. Such characteristics would lead to decreased EOs efficiencies as antimicrobial and antioxidant agents and limit their use as green and natural preservatives.

Another valorization-limiting characteristic is EOs' easy oxidation. Once deprived of the protective compartment in the plant matrix, EOs' constituents are easily prone to different chemical transformations. Indeed, as EOs are both thermo-sensitive and volatile, they are easily alterable [94]. Several factors could be responsible for the degradation of the chemical constituent of EOs. First, the plant's growth stage and the vegetable material's post-harvest storage conditions profoundly influence an EO's alteration. Besides, other factors related to handling or storing the oil itself will also lead to the acceleration of EOs' oxidation, such as temperature, light, and atmospheric oxygen availability. Indeed, the ultraviolet light and visible light are considered accelerators of the self-oxidation process by taking out hydrogen, leading to alkyl radicals' formation. The oxidation of terpenoids, for example, produces the $p$-Cymene (Figure 3). They also give rise to a range of stable oxidized products such as alcohols, ketones, and aldehydes [95].

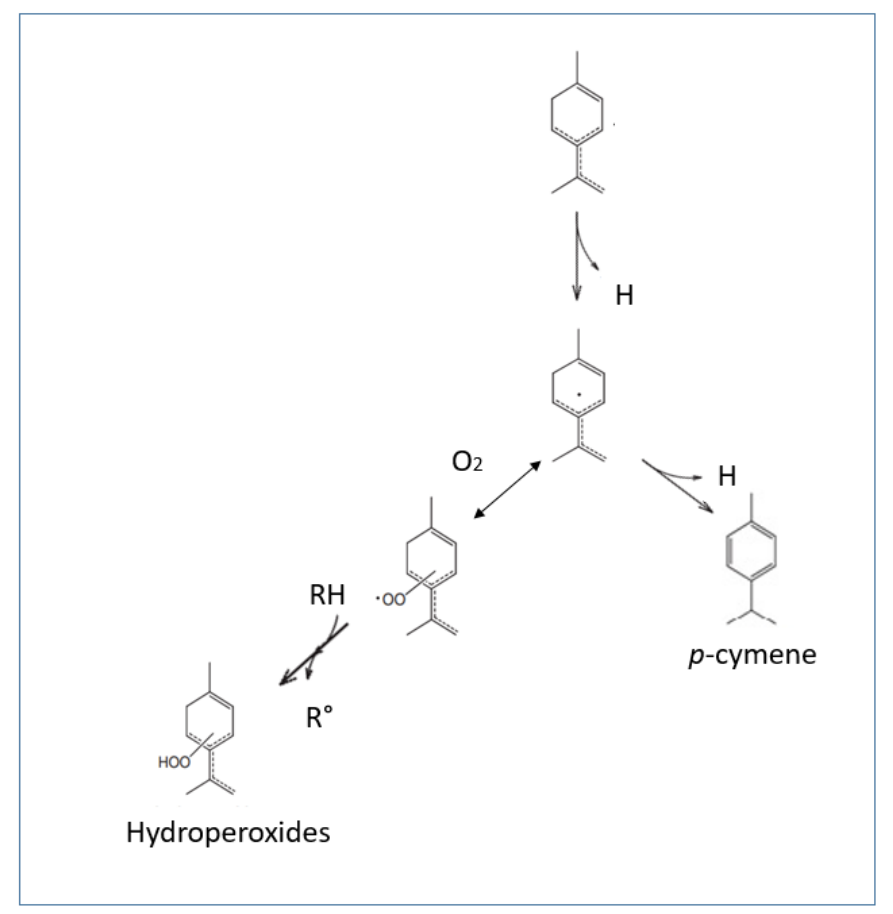

Figure 3. Oxidation of terpenoids adapted from Reference [95].

The encapsulation of EOs seems to be an attractive new approach to overcome all previously listed impediments [90]. Encapsulation consists of coating sensitive materials (solid, liquid, or gas) known as core material, with a protective layer called wall material [96]. EO encapsulation is a complex process with interrelated steps [97]. In this context, several research groups focused on EO encapsulation, and different techniques were proposed [98]. Accordingly, choosing the encapsulation method and the encapsulating material depend on specific parameters: targeted mean particle size, the physicochemical characteristics 
of wall and core ingredients, the intended applications of the encapsulated material, the release system of capsule content, production capacity, and cost [96,99].

Concretely, the EO encapsulation approach has succeeded to convince the research society of its efficacy. Firstly, the oxidation phenomenon has been avoided/retarded after EOs' encapsulation. Bakry et al. highlighted that basil EO's microencapsulation protected it against oxidation under accelerated storage conditions for 49 days [100]. In addition, EO encapsulation allows the preservation of their biological efficiencies during their storage, transport, and processing. The encapsulation of oregano EO into microspheres of native sorghum and rice starch significantly prolonged its antioxidant activity during storage [101].

Moreover, using encapsulation as a technological alternative to conceal EOs' highly undesirable taste has been repeatedly justified. Ghalem and Zouaoui suggested that adding Lavandula and Chamaemelum spp. EOs to yoghurt decreased its acceptability by panelists [102]. In addition, EO encapsulation represents an efficient approach to increase their bioactivity and bioavailability by ensuring their even distribution in the medium [103]. To overcome EO hydrophobic limitation, the outer protective layer, used in the encapsulation, acts as a hydrophilic barrier to EOs. In this context, Ben Jemaa et al. have pointed out that bulk thyme EO, with low water solubility, was roughly distributed in the medium and its action extent was therefore limited. On the contrary, when encapsulated in the nanoemulsion-based delivery system, its diffusion was homogeneously leading to more efficient antimicrobial activity [104].

In this context, multiple methods were developed for EOs' encapsulation, as follows.

The complex coacervation process: This process involves a liquid-liquid phase separation formed between two or more oppositely charged biopolymers from the initial solution, leading to coacervate formation around the active ingredient [100]. Mixtures between proteins and polysaccharides are generally used to prepare complex coacervates for encapsulation purposes. Encapsulation by complex coacervation can involve various steps for the formation of microcapsules: (i) an aqueous solution is prepared to contain two or more anionic and cationic polymers, (ii) the aqueous phase is mixed with a hydrophobic solution to produce a stable emulsion, (iii) a sudden change in $\mathrm{pH}$ and temperature induces the coacervation and the phase separation, and (iv) the polymer matrices harden by using a desolvating agent, high temperature, or a crosslinking agent (Figure 4) [105].

Recent studies showed that complex coacervation could be used by mixing two oppositely charged proteins with an affinity for an encapsulated bioactive component [106]. Efficient encapsulation yield with a protective effect was reported for vitamin B9 encapsulated in milk-derived protein coacervates. Complex coacervation is a mix of food proteins that constitutes a new, biosourced, and economically viable method suitable for entrapment and encapsulation of hydrophobic molecules such as EOs [106].

Liposomes: Liposomes are made with many phospholipids bilayers vesicles enclosing an internal aqueous volume [107]. The growing interest in liposomes can be attributed mainly to their property of mimicking biological cells. Accordingly, liposomes are highly biocompatible, making them an ideal candidate for a drug delivery system, with applications ranging from delivering enzymes, antibacterial drugs, fungicides, and adjuvants for vaccines [108]. The membrane structure can vary significantly, making it possible to create different liposomes with diverse characteristics and applications [109].

Nanoemulsion: In nanoemulsion, tiny EO droplets are confined to a cavity surrounded by a unique polymer membrane [110]. The EO dispersion in water is obtained through the chemical action of surfactants. It is highly recommended to encapsulate EO into nanoemulsion-based delivery systems for different reasons: non-toxic and non-irritant, high kinetic stability, capacity to solubilize hydrophobic bioactive molecules and to enhance their bioavailability, and suitability for human and veterinary uses [111]. The nanoencapsulation of EOs can be performed using multiple techniques, such as high-pressure homogenization [104], micro-fluidization [112], and sonication [113]. 
Solid lipid nanoparticles (SLN): These particles are made up of lipids (triacylglycerols or waxes), solid at room temperature, biodegradable, and non-toxic, stabilized by adding suitable surfactants [97]. Solid lipids instead of oils allow improving the control in releasing the active molecules due to its reduced mobility in a solid phase compared to the oily liquid phase [107]. They are generally obtained by preparing an oil in water emulsion at a temperature exceeding the lipid phase melting point, and then the cooling of produced emulsion, leading to crystallization of the lipid and the trap of the target molecules either in the core or on the wall of the obtained particles [97]. This technique is highly recommended in carrying lipophilic active components since it offers adequate protection, less leakage, and sustained release of EOs [114].

Core dispersed in an aqueous phase (anionic polymer)
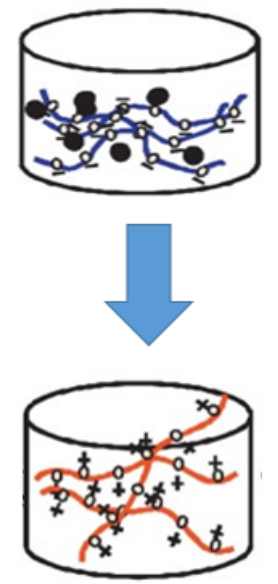

Addition of cationic polymer
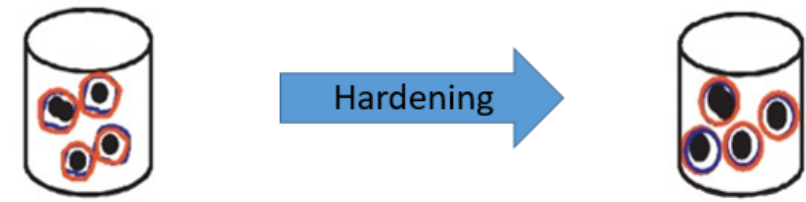

Coacervates with core in the center

Figure 4. Coacervation process adapted from Reference [105]. The bioactive molecule to be encapsulated (core) is first mixed with one polymer before adding the oppositely charged polymer. The complex coacervation process is generally spontaneous or induced by altering the physicochemical parameters ( $\mathrm{pH}$, temperature, ionic strength, etc.). This process leads to the formation of micrometric droplets $(5-10 \mu \mathrm{m})$ with entrapped bioactive molecules. At the end, stabilization can be performed using chemical or physical treatments.

\section{Main Properties of EOs}

The therapeutic properties of EOs are directly linked to the molecules that compose them. They present antioxidant, antimicrobial, and anti-inflammatory properties.

\subsection{Antimicrobial Activity}

Several studies tried to explain the mechanism of action of an EO towards bacteria. This mechanism's complexity is related to the chemical composition of EOs, which presents a high diversity of molecules (each molecule acts on a specific target). EOs can target the cell membrane, disrupting the cell energy status (the process of energy transduction coupled with the membrane and the solute transport) and the metabolic regulation. Sometimes, it modifies the expression of operons by inhibiting self-inducing mediators [115].

Many mechanisms of action are attributed to the interaction of EOs with the components of the cell membrane. The lipophilic character of molecules in EOs make them 
capable of penetrating the phospholipid double layer of the cell membrane, leading to a lack of regulation of the cell membrane, thereby disrupting the transportation of nutrients. Membrane transport can also dysregulate via disturbance of the ionic gradient on the cytoplasmic membrane's two sides. However, some bacteria strains have been able to develop mechanisms allowing it to counteract this effect through ion pump use [115].

EOs could affect the biosynthesis of lipids, including unsaturated fatty acids, thus modifying the cell membrane structure due to the hydrophobic characteristic. EOs in the bacterial cell, even in a concentration below the minimum inhibitory concentration (MIC), decrease the level of unsaturated fatty acids that are generally responsible for the membrane fluidity. For example, thymol, carvacrol, and eugenol can increase saturated fatty acids and decrease C18 unsaturated fatty acids. The action of EOs can also affect the enzymes responsible for the latter's biosynthesis [115].

Hundreds of in vitro studies were carried out to evaluate the effects of EOs on some pathogens, such as Gram-positive bacteria: Staphylococcus aureus and Bacillus subtilis, Gramnegative bacteria: Pseudomonas aeruginosa and Escherichia coli, yeasts: Candida albicans, and molds: Aspergillus niger. These six species are the most abundant infectious microorganisms, mainly because they are the most frequently tested [86]. Table 2 shows the minimum inhibitory concentration (MIC) (the lowest concentration of a chemical preventing a bacteria's visible growth) of EOs against some pathogens [27].

Table 2. List of recent studies that tested the antibacterial properties of some EOs against pathogens by identifying the minimum inhibitory concentration (MIC) of EOs.

\begin{tabular}{|c|c|c|c|}
\hline EOs & Bacteria & MIC & References \\
\hline $\begin{array}{l}\text { Cymbopogon spp. and } \\
\text { Cinnamomum verum }\end{array}$ & Escherichia coli & $\begin{array}{c}0.075 \% \text { to } 0.3 \%(v / v) \text { and } 0.0075 \%(v / v) \text {, } \\
\text { respectively }\end{array}$ & [116] \\
\hline $\begin{array}{c}\text { A. sativum, C. verum, } O \text {. } \\
\text { basilicum, S. aromaticum and } \\
\text { T. vulgaris }\end{array}$ & $\begin{array}{l}\text { Aeromonas hydrophila, A. jandaei and } \\
\text { Citrobacter freundii isolated from } \\
\text { diseased freshwater fish }\end{array}$ & $\mathrm{MIC} \leq 500 \mu \mathrm{g} / \mathrm{mL}$ & [117] \\
\hline Lavandula $x$ intermedia & $\begin{array}{c}\text { Streptococcus agalactiae and } \\
\text { Candida albicans }\end{array}$ & $\begin{array}{l}\text { MIC } 9-18 \mu \mathrm{g} / \mathrm{mL} \text { for Streptococcus } \\
\text { MIC } 9-18 \mu \mathrm{g} / \mathrm{mL} \text { for Candida }\end{array}$ & [118] \\
\hline Mentha arvensis & $\begin{array}{c}\text { Streptococcus agalactiae and } \\
\text { Candida albicans }\end{array}$ & $\begin{array}{l}\text { MIC } 18-36 \mu \mathrm{g} / \mathrm{mL} \text { for Streptococcus } \\
\text { MIC } 18-144 \mu \mathrm{g} / \mathrm{mL} \text { for Candida } \\
\text { MIC } 23.4 \mu \mathrm{g} / \mathrm{mL} \text { for M. luteus }\end{array}$ & [118] \\
\hline P. armeniaca & M. luteus, S. aureus and E. coli & $\begin{array}{c}\text { MIC } 23.4 \mu \mathrm{g} / \mathrm{mL} \text { for } S . \text { aureus } \\
\text { MIC } 11.7 \mu \mathrm{g} / \mathrm{mL} \text { for E. coli } \\
\text { MIC } 22.2 \mu \mathrm{g} / \mathrm{mL} \text { for M. luteus }\end{array}$ & [119] \\
\hline L. nobilis & M. luteus, S. aureus and B. subtilis & $\begin{array}{l}\text { MIC } 5.55 \mu \mathrm{g} / \mathrm{mL} \text { for } S \text {. aureus } \\
\text { MIC } 1.39 \mu \mathrm{g} / \mathrm{mL} \text { for } B \text {. subtilis }\end{array}$ & [119] \\
\hline M. alternifolia & K. pneumoniae, P. aerginosa, and E coli & MIC 0.5 and $4 \mu \mathrm{g} / \mathrm{mL}$ & [120] \\
\hline T. vulgaris & K. pneumoniae, $P$. aerginosa, and $E$ coli & MIC 1 to $16 \mu \mathrm{g} / \mathrm{mL}$ & [120] \\
\hline Garlic, cinnamon, and onion & L.monocytogenes & MIC respectively 100,100 , and $25 \mu \mathrm{g} / \mathrm{mL}$ & [121] \\
\hline
\end{tabular}

\subsection{AntiInflammatory Properties}

Inflammation is a physiological response caused by an infected or injured tissue in the body. Inflammatory processes can: (i) increase the permeability of mucosal endothelial cells and the interstitium's influx of blood leukocytes, (ii) cause the expression of cell adhesion molecules, such as vascular cell adhesion molecules (VCAM) and intercellular adhesion molecules (ICAM), (iii) upregulate the activity of several enzymes (oxygenase, peroxidase, and nitric oxide synthase) and the metabolism of arachidonic acid, and (iv) cause the release of pro-inflammatory cytokines [122-125].

EOs can interact with the signaling cytokines, the regulatory transcription factors, and the expression of pro-inflammatory genes in addition to their antioxidant activities. The mechanism of action may be indirect in an immunostimulatory reaction or direct via several mechanisms such as: 
Hyperemia, which accelerates the recruitment of leukocytes, promoting the antiinflammatory reactions (citrals, citronellal, and cuminal in external use),

- Blockage of the synthesis and secretion of mediators of inflammation (histamine, pro-inflammatory cytokines, prostaglandins, leukotrienes, nitric oxide, free radicals), thus acting at different levels of anti-inflammatory activity [126,127].

\section{EO and Inflammation: The Bovine Mastitis as a Paradigm Case}

The immunomodulatory activity of EOs in human medicine has been reported for a long time, presenting the much more complicated evidence than previously believed, and not only limited to antioxidant activity. The EO obtained from Lavandula angustifolia showed the capacity to increase phagocytosis and decrease pro-inflammatory cytokine production, counter-balancing the inflammatory signaling induced by experimental infection with S. aureus [128].

In both ruminants and monogastrics, identifying immunomodulatory molecules for bovine mastitis, or calf, pig, and chicken intestinal diseases, is a promising alternative strategy to using antibiotics that may result in resistance development in humans and animals. Although there is a growing interest in the use of EOs, few data are available on the degradation rate of EOs and their compounds in the gastrointestinal tract and the way they are prepared and fed to animals, e.g., whether they are micro-encapsulated or not [129].

In monogastric species like pigs, the integration of diet with $\mathrm{EO}$ can change the distribution of lymphocytes in the gut. It is unknown whether this effect is direct, e.g., related to EOs' interaction with the intestinal immune system, or indirect, via EOs' interaction with the resident microbiome, which changes its relationship with the resident immune system. By integrating diets with a mixture of carvacrol, cinnamaldehyde, and capsicum oleoresin, it was possible to decrease intraepithelial lymphocyte (IEL) population jejunum and ileum and increase lymphocyte in the lamina propria of early-weaned pigs [130]. Indeed, this information does not allow to understand the consequence of this immunomodulatory activity for the overall animal health. On one side, a decrease of the immune activation may protect the animal from the unwanted excess of immune stimulation, and prevent collateral damages related to inflammation. On the other hand, decreasing immune activity might also pave the way for a breakthrough of pathogens.

On the contrary, other EOs' activities are related to potentiating immune responses, such as improving serum lymphocyte proliferation rate, phagocytosis rate, immunoglobulin (Ig) G, IgA, IgM, C3, and C4 levels in piglets [131]. These results were recently confirmed by similar studies, demonstrating an increase of IgG and IgM after plant EO supplementation [132].

A recent study also reported the anti-inflammatory activity of encapsulated EO [133], demonstrated by a decrease of the major pro-inflammatory cytokines (Tumor necrosis factor alpha (TNF- $\alpha$ ) and interleukin 6 (IL-6)). However, even anti-inflammatory cytokines, like IL-10, are decreased, confirming that EO activities are more complex, and not one-sided.

The molecular basis of the immunomodulatory activity of EOs has not been investigated in-depth and may indeed change, depending on the specific EO used. Regarding oregano-derived EO, the immunomodulatory activity is related to downregulation of proinflammatory pathways, including the mitogen-activated protein kinase (MAPK), protein kinase $B(A k t)$, and nuclear factor $\kappa B(N F-k B)$ signaling pathways, which reflects on the decreased expression of inflammatory cytokines in the jejunum of pigs models [134].

The effects of dietary EO have been studied in the other primary livestock monogastric species, the chicken, albeit less intensively. The EOs have an evident immunomodulatory activity on mRNA expression in intestinal cells on IL-17A, Interferon (INF) $\alpha$, INF- $\gamma$, Transforming growth factor (TGF) $\beta$, and IL-10 [135]. Carvacrol can decrease the inflammatory activity induced by lipopolysaccharides (LPS) treatment by downregulating the mRNA expression of some pro-inflammatory cytokines, including TNF- $\alpha$, IL-1 $\beta$, IL-6, IL-8, and of pathogen-associated molecular pattern membrane receptors, such as TLR2 and 4, and the 
downstream pathways related to them, such as NF- $\mathrm{KB}$ [136], after LPS challenge, demonstrating the potential anti-inflammatory activities of this $\mathrm{EO}$ against intestinal infection. A study on Minthostachys verticillata EO with immunomodulatory activity on human T cells and anti-inflammatory activities showed its capability to increase macrophage phagocytosis and oxidative burst in a Balb/c mice model. Moreover, this EO can decrease neutrophil chemotaxis to the mammary gland, and downregulate pro-inflammatory cytokines', such as IL-1 $\beta$ and TNF- $\alpha$, mRNA expression. Consistently, the anti-inflammatory cytokine IL-10 is also upregulated. Given that $M$. verticillata $\mathrm{EO}$ was also shown to induce a decrease of the bacterial count in the glands of mice experimentally infected with E. faecium, this model demonstrated that this EO could boost the innate immunity to help to resolve inflammation [137].

In ruminants, the anti-inflammatory activity of EO was also reported in a model of Sub-Acute Ruminal Acidosis: introducing a mixture of EO and polyphenols in the diet could reduce the number of circulating neutrophils and of the acute phase proteins Serum Amyloid A, Haptoglobin, and Lipopolysaccharide Binding proteins, that are regarded as markers of inflammation in cows [138,139].

The mammary gland's inflammation, also called mastitis, is one of the most frequent and costly dairy cows' diseases, mostly caused by intramammary infection due to bacteria and other microorganisms [140]. Bovine mastitis is an inflammation of the udder. It is the result of an infection of the udder by bacteria, yeasts, or viruses. Mastitis or inflammation of the mammary gland develops when a pathogen crosses the teat canal barriers and multiplies in the milk. When the immune defense mechanisms fight this infection quickly and effectively, mastitis will be mild and transient. On the other hand, when the defense mechanisms are compromised, during parturition, or when the pathogen has evasion mechanisms against the immune system, mastitis will be more severe or become chronic [141].

The intensity of the inflammatory response will determine the type of mastitis: subclinical or clinical. Major pathogens related to mastitis include Escherichia coli, Staphylococcus aureus, Streptococcus uberis, Streptococcus dysgalactiae, and Streptococcus agalactiae, and other bacteria, such as Arcanobacterium pyogenes, Staphylococcus non-aureus, Pseudomonas aeruginosa, Nocardia asteroides, Clostridium perfringens, Mycobacterium spp., Listeria monocytogenes, and many others can be found as associated with mastitis. Following clinical signs, bacterial infiltration reaction in dairy cows develops following two different clinical events: clinical mastitis and subclinical mastitis [142]. The clinical mastitis usually recapitulates acute inflammation's significant features: the infected udder becomes swollen, red, hot, and sometimes painful to be touched. Clinical mastitis significantly affects milk quality and quantity.

The resulting milk looks like an inflammatory exudate, hemorrhagic or sometimes purulent, exhibits the formation of flakes and clots, decreased protein, fat, and lactose contents. The exudate is infiltrated by cells migrated from the blood via diapedesis, mostly neutrophil granulocytes, and are defined as somatic cells (SC) [141]. Subclinical mastitis is more challenging to detect. In most of the cases, the only sign is the increase of SC. Bovine mastitis causes a drop in milk production in the affected quarters. This decrease is most marked in the event of clinical mastitis. Subclinical inflammations can also reduce milk productivity by up to $40 \%$. As a result, veterinary costs, pharmacological treatment, and milk wastage due to treatments impact the farm's profitability [143]. Beside the decrease in milk production in animals with mastitis, the milk containing somatic cells is removed from the dairy chain, increasing the economic burden [144].

The conventional therapy against mastitis still includes aggressive treatment with antibiotics which, although necessary, is not fully efficient, and presents several drawbacks. Extending over the critical use of antibiotics is at the background of the development of antimicrobial resistance that can persist in the bacterial community [145], as shown for Streptococcus agalactiae and S. aureus [146], causing antibiotic resistance in humans as well [142]. Alternative and complementary approaches are therefore investigated, such as using EOs. 
In vitro studies have demonstrated the antibacterial activity of EOs against several pathogens that can cause mastitis, such as, among the others, L. monocytogenes, Salmonella typhimurium, E.coli, and S. aureus [147]. The EOs' chemical constituents promote bacterial cell wall and membrane damages, such as cell wall degradation, protein denaturation, and destabilization of proton motive force. Given their lipophilic nature, EOs can penetrate the lipid bi-layer of the bacterial cell membrane, causing loss of integrity and structural organization [148]. In general, Gram-positive bacteria are more sensitive than Gramnegative to disruptive activity, probably due to the lipopolysaccharides at the outside of the cell wall [149].

Their natural origin, coupled with lower side effects and the limited development of resistance after prolonged use, have identified EOs as promising therapeutics agents against mastitis, both in vitro and in vivo [150].

In vitro studies have been carried out to test the effects of selected EOs on the cells present in the mammary glands, such as epithelial mammary gland cells, or against bacteria involved in mastitis development. The activity of EOs against Methicillin-resistant S. aureus (MRSA) may be related to the disruption of biofilms in a syntrophic consortium within a self-produced matrix of extracellular polymeric substances (EPS). Biofilm production is a strictly coordinated process by which planktonic bacteria switch from free-floating forms to sessile anchored cells embedded in self-produced EPS [151].

Remarkably, several studies demonstrated that the major components of EOs, when isolated, appear to be less active against bovine pathogens than does the full-fledged EO, suggesting the hypothesis that, along with the individual antibacterial activity of each component, the various molecules present in the EO act synergistically to fulfil an antibacterial activity [148].

As expected, there are very limited and less conclusive in vivo studies. Moreover, in many cases, the molecules used for in vivo studies were not tested for the presence of lipopolysaccharides or other pro-inflammatory molecules, which may bias the experimental design, particularly when directly infused in the mammary gland. Most in vivo studies, including the treatment with external application, do not provide enough scientific evidence to support the use of the EO directly in the mammary gland.

On the other hand, as mentioned previously, bibliographic research highlights a low number of in vivo experiments made on the use of EOs in treating mastitis: Abboud et al. studied the effect of $10 \%$ of a mixture of Thymus vulgaris and Lavandula angustifolia, by intramammary infusion and external application on the quarter. After four days of treatment, they discovered a substantial decrease in the bacterial colony count. The most potent antibacterial activity was achieved by massaging the udder with the mixture of EOs [152].

Another study was conducted to evaluate the effect of Origanum vulgare by intramammary infusion: $0.9 \mathrm{~mL}$ of EO was given twice a day for three days. S. aureus and E. coli were not detected in milk after the treatment [153]. The intramammary infusion of sage EO to ewes affected with subclinical mastitis resulted in a significant decrease in somatic cell count 24 and $48 \mathrm{~h}$ post-treatment. On the other hand, Lefevre et al. treated 55 cases of mastitis with a mixture of EOs containing Thymus vulgaris, Rosmarinus verbenone, and Laurus nobilis (1.5\% each in $10 \mathrm{~mL}$ of sunflower oil), and 45 mastitis with a combination of Thymus vulgaris and Rosmarinus verbenone (6\% of each in sunflower oil or water). The results were unsatisfactory: The recovery rate was only $40 \%$ [154].

Several hypotheses were advanced trying to explain these contradictory observations: (i) milk can interact with the EO, resulting in an alteration of their antibacterial properties, (ii) the concentration of the EO used in the in vivo treatment is not enough, and (iii) the excipient could modify the physicochemical characteristics of EOs [155].

Antioxidant Activity and Mechanisms of Action

EOs obtained from different plants are a source of natural antioxidants [156]. Most EOs have the virtue of being non-toxic - the literature has demonstrated that, compared 
to inorganic supplements, plant-derived products such as EOs are less toxic, residuefree, and thought to be ideal growth promoters for both milk and beef production and quality [156,157]. In addition, transition metals such as $\mathrm{Fe}$ and $\mathrm{Cu}$, often given as mineral supplementation, favor the formation of highly reactive free radicals in meat, accelerating its oxidation $[158,159]$. However, in high concentrations, they can exert toxicity, such as necrosis. Hence, it is a common practice in the study of EOs, although not entirely correct, to identify natural antioxidants as "molecules able to react with radicals" or molecules that present the reducing power to counteract the oxidative stress caused by radicals $[156,160]$. Accordingly, there are several methods used to examine the antioxidant properties of EOs. The most common tests used to screen the antioxidant activity of EOs are based on the in vitro reaction of the phytochemicals with some colored persistent radicals (e.g., 2,2-diphenyl-1-picrylhydrazyl (DPPH ${ }^{\bullet}$ ) or 2,2'-azino-bis(3-ethylbenzothiazoline-6-sulfonic acid) $\mathrm{ABTS}^{\bullet+}$ assay) (antiradical) or with some oxidizing nonradical species such as $\mathrm{Fe}^{3+}$ ions (e.g., ferric reducing antioxidant power (FRAP) assay) [161]. From a mechanistic point of view, these methods are classified as electron transfer (ET)-based assays, contrary to hydrogen atom transfer (HAT)-based assays, also widely used, which include oxygen radical absorbance capacity (ORAC) assay, radical-trapping antioxidant parameter (TRAP) assay, crocin bleaching assay using 2,2' -azobis-2-methyl-propanimidamide dihydrochloride $(\mathrm{AAPH})$ as a radical generator, and $\beta$-carotene bleaching (BCB) assay $[162,163]$. In Table 3 , we summarized some studies on the in vitro antioxidant activity of the selected EOs.

Many studies exploring the bioactivity of EOs have mainly attributed their antioxidant capacity to terpenoids with phenolic groups such as carvacrol, methyl chavicol, thymol, and eugenol, as they can donate hydrogen atoms to free radicals and transform them into more stable products $[162,164]$. For example, about $80 \%$ of oregano EOs are constituted by carvacrol and thymol, mainly responsible for its antioxidant activity $[165,166]$. Similarly, EOs from other aromatic plant species, like lemon balm, basil, thyme, and sage, have also been established as rich sources of antioxidants [162]. The study conducted by Viuda-Martos and co-workers demonstrated the ability EOs from oregano (Origanum vulgare), rosemary (Rosmarinus officinalis), and sage (Salvia officinalis) to chelate $\mathrm{Fe}^{2+}$, with rosemary EO displaying the highest effect (76.06\%). Moreover, oregano EO showed the most increased antioxidant activity in the Rancimat test [167]. Tunisian Thymus capitatus EO's antioxidant activity, mainly composed of carvacrol, $p$-cymene, and $\gamma$-terpinene, was compared with butylated hydroxyanisole (BHA) and Butylated hydroxytoluene (BHT) by DPPH and thiobarbituric acid-reactive species (TBARS) methods, evidencing better antioxidant properties [168]. On the other hand, Kulisic et al. revealed that the antioxidant activity of $O$. vulgare EO was less effective than ascorbic acid (AA), but comparable with the $\alpha$-tocopherol and BHT, based on the BCB test, DPPH radical scavenging method, and thiobarbituric acid-reactive species (TBARS) assay [169]. Furthermore, in vivo experiments carried out in pigs fed with diets containing $O$. vulgare crude herbal drug promoted significantly improved stability and lower cholesterol oxide content in raw belly bacon than controls after 34 weeks of storage [170]. In line with these findings, Botsoglou et al. demonstrated that laying hens fed with a Thymus vulgaris-enriched diet ( $3 \%$ ground herb) led to an increased storage time (over 60 days) in the refrigerator, mostly due to reduced oxidation of liquid yolk [171]. Additionally, higher enzyme levels of the antioxidative enzymes, namely superoxide dismutase (SOD) and glutathione peroxidase (GPx), were found in ageing rats dietary supplemented with thyme oil or thymol [172]. Studies conducted in White pigs demonstrated that rosemary EO $(150 \mathrm{mg} / \mathrm{kg})$ significantly reduced the generation of TBARS and hexanal, and carbonyls, indicators of lipid and protein oxidation, respectively $[165,173]$. A study developed by Takayama et al. showed that pre-treatment of rats with $R$. officinalis EO $(50 \mathrm{mg} / \mathrm{kg})$ protected against the gastric injury induced by ethanol, probably by modulating the activities of SOD and GPx, and increasing or maintaining the levels of glutathione (GSH) [174]. In vitro experiments dealing with the DPPH scavenging activity of Nigella sativa EO revealed that its potent antioxidant activity (The half maximal inhibitory concentration $\left(\mathrm{IC}_{50}\right)=19 \mu \mathrm{g} / \mathrm{mL}$ ) could be attributed to the presence of oxy- 
genated monoterpenes such as thymol and thymoquinone [175]. Furthermore, N. sativa EO strongly inhibited tert-Butyl hydroperoxide $(t-\mathrm{BuOOH})$ induced $2^{\prime}, 7^{\prime}$-dichlorofluorescin diacetate (DCFH) oxidation with an $\mathrm{IC}_{50}$ of $1.0 \mu \mathrm{g} / \mathrm{mL}$ in WS- 1 cells, indicating its ability to inhibit reactive oxygen species (ROS) production [176]. In vivo assays demonstrated that $N$. sativa EO holds the potential to significantly improve the oxidant status of normal rats by enhancing the activity of several antioxidant enzymes, namely glutathione reductase and glutathione transferase [177]. Singh et al. also showed the strong antioxidant effect of $N$. sativa EO in the rapeseed oil system, evidencing comparable results to BHA and BHT effects at the $6 \mathrm{mg}$ levels [158].

Table 3. Antioxidant activity of selected EOs.

\begin{tabular}{|c|c|c|c|c|}
\hline $\begin{array}{l}\text { Essential Oil } \\
\text { (Plant Species) }\end{array}$ & $\begin{array}{l}\text { Location } \\
\text { (Plant Part) }\end{array}$ & Main Components & In Vitro Assay, Bioactivity & References \\
\hline \multirow{4}{*}{$\begin{array}{l}\text { Sage (Salvia } \\
\text { officinalis L.) }\end{array}$} & $\begin{array}{l}\text { Saudi Arabia } \\
\text { (leaves) }\end{array}$ & $\begin{array}{c}\text { Camphor }(20.3 \%), 1,8 \text {-cineole }(15.0 \%), \alpha \text {-thujone } \\
(14.9 \%) \text {, viridiflorol }(9.9 \%) \text {, carvone }(6.2 \%), \\
\beta \text {-thujone }(5.7 \%)\end{array}$ & $\mathrm{DPPH}, \mathrm{IC}_{50}=970 \mu \mathrm{g} / \mathrm{mL}$ & [178] \\
\hline & $\begin{array}{l}\text { Morocco } \\
\text { (leaves) }\end{array}$ & $\begin{array}{c}\text { Camphor }(24.1 \%), \alpha \text {-thujone }(21.4 \%), 1,8 \text {-Cineole } \\
(16.5 \%), \alpha \text {-pinene }(11.2 \%), \text { camphene }(6.9 \%)\end{array}$ & $\begin{array}{l}\text { DPPH, } \mathrm{IC}_{50}=2.12 \mathrm{mg} / \mathrm{mL}(>\mathrm{Q} \text { and AA); } \\
\text { BCB, } \mathrm{RC}_{50}=3.78 \mathrm{mg} / \mathrm{mL}(>\mathrm{Q} \text { and BHT); } \\
\text { FRAP, } \mathrm{EC}_{50}=2.98 \mathrm{mg} / \mathrm{mL}(>\mathrm{Q} \text { and AA) }\end{array}$ & [179] \\
\hline & $\begin{array}{l}\text { Spain (leaves } \\
\text { and flowers) }\end{array}$ & $\begin{array}{l}\text { Camphor }(25.0 \%), 1,8 \text {-cineole }(24.7 \%) \text {, camphene } \\
(7.6 \%), \alpha \text {-pinene }(6.8 \%), \alpha \text {-terpinyl acetate }(6.0 \%)\end{array}$ & $\begin{array}{c}\text { DPPH, } \mathrm{IC}_{50}=4.20 \mathrm{mg} / \mathrm{mL}(>\mathrm{AA} \text { and } \\
\mathrm{BHT}^{2} ; \mathrm{TBARS}, \mathrm{EC}_{50}=35.56 \mathrm{mg} / \mathrm{mL}(>\mathrm{AA} \\
\text { and } \mathrm{BHT}) ; \mathrm{FIC}, \mathrm{EC}_{50}=7.16 \mathrm{mg} / \mathrm{mL}(<\mathrm{AA} \\
\text { and BHT); Rancimat, } \mathrm{AAI}=1.07(<\mathrm{AA} \\
\text { and BHT })\end{array}$ & {$[167,180]$} \\
\hline & $\begin{array}{r}\text { Tunisia } \\
\text { (leaves) }\end{array}$ & $\begin{array}{c}\text { Camphor }(25.1 \%), \alpha \text {-thujone }(18.8 \%), 1,8 \text {-cineole } \\
(14.1 \%) \text {, viridiflorol }(8.0 \%), \beta \text {-thujone }(4.5 \%) \text {, and } \\
\beta \text {-caryophyllene (3.3\%) }\end{array}$ & $\begin{array}{c}\mathrm{DPPH}, \mathrm{IC}_{50}=6.7 \mathrm{mg} / \mathrm{mL}(>\mathrm{BHT}) ; \mathrm{FRAP} \\
\mathrm{IC}_{50}=28.4 \mathrm{mg} / \mathrm{mL}(>\mathrm{BHT}) ; \mathrm{LAP} \\
\text { inhibition, } \mathrm{IC}_{50}=9.6 \mathrm{mg} / \mathrm{mL} \\
(>\alpha \text {-tocopherol })\end{array}$ & [181] \\
\hline \multirow{4}{*}{$\begin{array}{l}\text { Laurel } \\
\text { (Laurus } \\
\text { nobilis L.) }\end{array}$} & $\begin{array}{l}\text { Morocco; } \\
\text { (Flowers) }\end{array}$ & $\begin{array}{c}\text { 1.8-Cineole }(45.0 \%), \alpha \text {-caryophyllene }(7.5 \%), \\
\text { germacradienol }(6.1 \%) \text {, limonene }(4.7 \%), \\
\alpha \text {-pinene }(3.0 \%), \text { germacrene D }(3.1 \%)\end{array}$ & $\begin{aligned} \mathrm{DPPH}, \mathrm{IC}_{50} & =82.01 \mu \mathrm{g} / \mathrm{mL}(>\mathrm{BHT} \\
& \text { and AA })\end{aligned}$ & [182] \\
\hline & $\begin{array}{c}\text { Turkey } \\
\text { (leaves) }\end{array}$ & $\begin{array}{c}\text { 1,8-Cineole }(51.8 \%), \alpha \text {-terpinyl acetate }(11.2 \%) \\
\text { sabinene }(10.1 \%), \alpha \text {-terpineol }(5.2 \%)\end{array}$ & $\begin{array}{c}\text { DPPH, } \mathrm{IC}_{50}=59.2 \mu \mathrm{g} / \mathrm{mL}(>\mathrm{BHT} \text { and AA }) \\
\text { BCB, RAA }=76.8 \%(<\text { BHT and AA })\end{array}$ & [183] \\
\hline & $\begin{array}{l}\text { Lebanon } \\
\text { (leaves) }\end{array}$ & $\begin{array}{c}\text { 1,8-Cineole }(35.2 \%), 1-p \text {-menthen-8-ethyl acetate } \\
(13.5 \%), \text { linalool }(7.1 \%), \text { sabinene }(6.2 \%) \\
\alpha \text {-pinene }(5.7 \%)\end{array}$ & $\begin{array}{l}\mathrm{DPPH}, \mathrm{IC}_{50}=53.5 \mu \mathrm{g} / \mathrm{mL}(>\mathrm{AA}) ; \mathrm{BCB} \\
\quad \mathrm{IC}_{50}=35.6-38.9 \mu \mathrm{g} / \mathrm{mL}(>\mathrm{PG})\end{array}$ & [184] \\
\hline & $\begin{array}{l}\text { Lebanon } \\
\text { (seeds) }\end{array}$ & $\begin{array}{c}\beta \text {-Ocimene }(21.8 \%), 1,8 \text {-cineole }(9.4 \%), \alpha \text {-pinene } \\
(3.7 \%), \beta \text {-pinene }(2.1 \%)\end{array}$ & $\begin{array}{c}\text { DPPH, } \mathrm{IC}_{50}=66.1 \mu \mathrm{g} / \mathrm{mL}(>\mathrm{AA}) ; \mathrm{BCB} \\
\mathrm{IC}_{50}=41.1-45.9 \mu \mathrm{g} / \mathrm{mL}(>\mathrm{PG})\end{array}$ & [184] \\
\hline $\begin{array}{l}\text { Coriander } \\
\text { (Coriandrum } \\
\text { sativum L.) }\end{array}$ & $\begin{array}{l}\text { Slovakia } \\
\text { (fruit) }\end{array}$ & $\begin{array}{l}\beta \text {-Linalool }(66.1 \%) \text {, camphor }(8.3 \%) \text {, geranyl } \\
\text { acetate }(6.9 \%) \text {, cymene }(6.4 \%)\end{array}$ & $\mathrm{DPPH}, \mathrm{IC}_{50} \sim 39.38 \mathrm{mg}$ TEAC/L & [185] \\
\hline \multirow{3}{*}{$\begin{array}{l}\text { Rosemary } \\
\text { (Rosmarinus } \\
\text { officinalis L.) }\end{array}$} & $\begin{array}{l}\text { Morocco } \\
\text { (leaves) }\end{array}$ & $\begin{array}{c}\text { 1,8-Cineole }(42.3 \%) \text {, camphor }(14.8 \%), \alpha \text {-pinene } \\
(8.9 \%), \beta \text {-pinene }(6.3 \%), \alpha \text {-terpineol }(5.6 \%) \\
\text { borneol }(4.9 \%)\end{array}$ & $\begin{array}{l}\text { DPPH, } \mathrm{IC}_{50}=4.82 \mathrm{mg} / \mathrm{mL}(>\mathrm{Q} \text { and } \mathrm{AA}) ; \\
\mathrm{BCB}, \mathrm{RC}_{50}=5.79 \mathrm{mg} / \mathrm{mL}(>\mathrm{Q} \text { and } \mathrm{BHT}) \\
\mathrm{FRAP}, \mathrm{EC}_{50}=5.62 \mathrm{mg} / \mathrm{mL}(>\mathrm{Q} \text { and } \mathrm{AA})\end{array}$ & [179] \\
\hline & $\begin{array}{c}\text { Serbia } \\
\text { (leaves) }\end{array}$ & $\begin{array}{l}\text { Limonene (21.7\%), camphor (21.6\%), } \alpha \text {-pinene } \\
(13.5 \%), \text { Z-linalool oxide }(10.8 \%)\end{array}$ & $\mathrm{DPPH}, \mathrm{IC}_{50}=3.82 \mu \mathrm{L} / \mathrm{mL}(<\mathrm{BHT})$ & [186] \\
\hline & $\begin{array}{c}\text { Serbia } \\
\text { (aerial parts) }\end{array}$ & $\begin{array}{c}\text { 1,8-Cineole (43.8\%), camphor (12.5\%), } \alpha \text {-pinene } \\
(11.5 \%), \beta \text {-pinene }(8.2 \%)\end{array}$ & $\mathrm{DPPH}, \mathrm{IC}_{50}=77.6 \mu \mathrm{L} / \mathrm{mL}$ (= $\alpha$-tocopherol) & [187] \\
\hline \multirow{3}{*}{$\begin{array}{l}\text { Conehead } \\
\text { thyme } \\
\text { (Thymus } \\
\text { capitatus) }\end{array}$} & $\begin{array}{c}\text { Morocco } \\
\text { (aerial parts) }\end{array}$ & $\begin{array}{c}p \text {-Cymene }(18.9 \%) \text {, carvacrol }(13.4 \%) \text {, geranyl } \\
\text { acetate }(12.2 \%) \text {, borneol }(10.2 \%)\end{array}$ & $\mathrm{DPPH}, \mathrm{IC}_{50}=103 \mu \mathrm{g} / \mathrm{mL}(>\mathrm{AA})$ & [188] \\
\hline & $\begin{array}{c}\text { Tunisia } \\
\text { (aerial parts) }\end{array}$ & $\begin{array}{c}\text { Carvacrol (65.6-80.7\%), } p \text {-cymene }(4.8-8.9 \%), \\
\gamma \text {-terpinene }(5.3-13.7 \%), \beta \text {-caryophyllene } \\
(1.8-3.2 \%)\end{array}$ & $\begin{array}{c}\text { DPPH, } \mathrm{IC}_{50} \sim 250 \mu \mathrm{g} / \mathrm{mL}(<\mathrm{BHT}) ; \mathrm{TBARS}, \\
\mathrm{IC}_{50}<100 \mu \mathrm{g} / \mathrm{mL}\end{array}$ & [168] \\
\hline & $\begin{array}{l}\text { Algeria } \\
\text { (leaves) }\end{array}$ & $\begin{array}{c}\text { Thymol }(51.2 \%) \text {, carvacrol }(12.6 \%) \text {, } \\
\gamma \text {-terpinene }(10.3 \%)\end{array}$ & $\begin{array}{c}\mathrm{DPPH}, \mathrm{IC}_{50}=0.62 \mu \mathrm{g} / \mathrm{mL}(<\mathrm{BHA}, \mathrm{AA}, \\
\text { and thymol }) ; \mathrm{FRAP}, \mathrm{EC}_{50}=2.13 \mu \mathrm{g} / \mathrm{mL} \\
(<\mathrm{BHA}, \mathrm{AA}, \text { and thymol }) ; \mathrm{TAC}, \\
\mathrm{EC}_{50}=0.78 \mu \mathrm{g} / \mathrm{mL}(<\mathrm{BHA}, \mathrm{AA}, \\
\text { and thymol })\end{array}$ & [189] \\
\hline
\end{tabular}


Table 3. Cont.

\begin{tabular}{|c|c|c|c|c|}
\hline $\begin{array}{l}\text { Essential Oil } \\
\text { (Plant Species) }\end{array}$ & $\begin{array}{l}\text { Location } \\
\text { (Plant Part) }\end{array}$ & Main Components & In Vitro Assay, Bioactivity & References \\
\hline \multirow{3}{*}{$\begin{array}{l}\text { Black cumin } \\
\text { (Nigella } \\
\text { sativa })\end{array}$} & $\begin{array}{l}\text { Austria } \\
\text { (seeds) }\end{array}$ & $\begin{array}{c}\text { Thymoquinone }(30-48 \%), p \text {-cymene }(7-15 \%), \\
\text { carvacrol }(6-12 \%), 4 \text {-terpineol }(2-7 \%), \text { longifolene } \\
(1-8 \%), t \text {-anethole }(1-4 \%)\end{array}$ & $\begin{array}{c}\mathrm{DPPH}, \mathrm{IC}_{50}=460 \mu \mathrm{g} / \mathrm{mL}(>\mathrm{BHT}, \mathrm{AA}, \mathrm{Q}, \\
\text { carvacrol, and thymoquinone); }{ }^{\bullet} \mathrm{OH}, \\
\mathrm{IC}_{50}=0.011 \mu \mathrm{g} / \mathrm{mL}(<\text { carvacrol } \\
\text { and thymoquinone })\end{array}$ & [76] \\
\hline & Iran (seeds) & $\begin{array}{c}\text { Thymoquinone }(20.3 \%) \text {, camphene }(11.0 \%) \text {, } \\
\text { thymol }(10.1 \%), \beta \text {-pinene }(7.0 \%), \alpha \text {-thujene } \\
(6.0 \%), \gamma \text {-terpinene }(5.1 \%)\end{array}$ & $\begin{array}{c}\mathrm{DPPH}, \mathrm{IC}_{50}=19 \mu \mathrm{g} / \mathrm{mL}(>\mathrm{BHA}, \mathrm{AA} \text {, and } \\
\text { thymoquinone, but }<\alpha \text {-thujene, } \beta \text {-pinene, } \\
\quad p \text {-cymene, and } \gamma \text {-terpinene) }\end{array}$ & [175] \\
\hline & $\begin{array}{l}\text { Tunisia } \\
\text { (seeds) }\end{array}$ & $\begin{array}{l}p \text {-Cymene }(60.5 \%), \alpha \text {-thujene }(6.9 \%), \gamma \text {-terpinene } \\
(3.5 \%) \text {, thymoquinone }(3.0 \%), \beta \text {-pinene }(2.4 \%), \\
\text { carvacrol }(2.4 \%), \text { terpinen- } 4 \text {-ol }(2.1 \%)\end{array}$ & $\begin{array}{c}\text { DCFH (ROS production), } \mathrm{IC}_{50}=1 \mu \mathrm{g} / \mathrm{mL} \\
(<\mathrm{Q})\end{array}$ & [176] \\
\hline \multirow{4}{*}{$\begin{array}{l}\text { Cade } \\
\text { (Juniperus } \\
\text { oxycedrus) }\end{array}$} & $\begin{array}{l}\text { Tunisia } \\
\text { (leaves) }\end{array}$ & $\begin{array}{c}\beta \text {-Phellandrene }(36.8 \%), \alpha \text {-terpinolene }(13.2 \%) \text {, } \\
\beta \text {-myrcene }(9.1 \%), \alpha \text {-campholenal }(9.0 \%), \text { and } \\
p \text {-cymene }(6.0 \%)\end{array}$ & $\begin{array}{c}\text { DPPH, } \mathrm{IC}_{50}=20.1 \mu \mathrm{g} / \mathrm{mL}(<\mathrm{BHT}) ; \mathrm{FRAP}, \\
15.9 \mu \mathrm{mol} \mathrm{Fe} \mathrm{Fe}^{2+} / \mathrm{g}\end{array}$ & [190] \\
\hline & $\begin{array}{c}\text { Turkey } \\
\text { (needles) }\end{array}$ & $\begin{array}{c}\text { Caryophyllene oxide }(31.6 \%), \alpha \text {-pinene }(24.3 \%), \\
\text { caryophyllene }(10.0 \%)\end{array}$ & $\begin{array}{l}\text { DPPH, } \mathrm{IC}_{50}<40 \mu \mathrm{g} / \mathrm{mL}(<\mathrm{BHA} \text { and BHT }) ; \\
\text { FRAP, } 179.6 \mu \mathrm{mol} \mathrm{TX} / \mathrm{g}(<\mathrm{BHA} \text { and BHT })\end{array}$ & [191] \\
\hline & $\begin{array}{l}\text { Turkey } \\
\text { (cones) }\end{array}$ & $\begin{array}{c}\beta \text {-Pinene }(29.9 \%), \alpha \text {-pinene }(26.6 \%), \text { limonene } \\
(9.7 \%)\end{array}$ & $\begin{array}{l}\text { DPPH, } \mathrm{IC}_{50}<40 \mu \mathrm{g} / \mathrm{mL}(<\mathrm{BHA} \text { and } \mathrm{BHT}) \\
\text { FRAP, } 415.38 \mu \mathrm{mol} \mathrm{TX} / \mathrm{g}(<\mathrm{BHA} \text { and } \mathrm{BHT})\end{array}$ & [191] \\
\hline & $\begin{array}{c}\text { Algeria } \\
\text { (aerial parts) }\end{array}$ & $\begin{array}{c}\alpha \text {-Pinene }(37.8 \%) \text {, abietadiene }(8.3 \%) \text {, bulnesol } \\
(7.2 \%) \text {, manoyl oxide }(5.0 \%) \text {, germacrene D }(4.8 \%)\end{array}$ & $\begin{array}{c}\mathrm{DPPH}, \mathrm{IC}_{50}=91.25 \mathrm{mg} / \mathrm{mL}(>\mathrm{AA}) ; \mathrm{FRAP} \\
0.97 \mu \mathrm{mol} \mathrm{TX} / \mathrm{g}(<\mathrm{AA}) ; \mathrm{ABTS}, 5.82 \mu \mathrm{mol} \\
\mathrm{TX} / \mathrm{g}(<\mathrm{AA})\end{array}$ & [192] \\
\hline \multirow{2}{*}{$\begin{array}{l}\text { Geranium } \\
\text { (Pelargonium } \\
\text { graveolens) }\end{array}$} & India (leaves) & $\begin{array}{c}\text { Citronellol }(37.0 \%) \text {, geraniol }(18.0 \%) \text {, citronellyl } \\
\text { formate }(5.5 \%) \text {, linalool }(4.1 \%) \text {, rose oxide }(2.4 \%) \text {, } \\
\text { geranyl formate }(2.2 \%)\end{array}$ & $\begin{array}{c}\mathrm{DPPH}, \mathrm{IC}_{50}=18.02 \mu \mathrm{g} / \mathrm{mL}(>\mathrm{AA}) ; \mathrm{NO} \\
\mathrm{IC}_{50}=19.98 \mu \mathrm{g} / \mathrm{mL}(>\mathrm{AA})\end{array}$ & {$[193]$} \\
\hline & Egypt (leaves) & $\begin{array}{l}\beta \text {-Citronellol }(35.9 \%) \text {, geraniol }(11.7 \%) \text {, citronellyl } \\
\text { formate }(11.4 \%) \text {, linalool }(9.6 \%),(+) \text {-isomenthone } \\
(6.4 \%), \sigma \text {-selinene }(5.5 \%)\end{array}$ & $\begin{aligned} \mathrm{DPPH}, \mathrm{IC}_{50} & =6.2 \mu \mathrm{g} / \mathrm{mL}(>\mathrm{BHT}) ; \mathrm{BCLA}, \\
\mathrm{IC}_{50} & =4.1 \mu \mathrm{g} / \mathrm{mL}(>\mathrm{BHT})\end{aligned}$ & [194] \\
\hline \multirow{3}{*}{$\begin{array}{l}\text { Oregano } \\
\text { (Origanum } \\
\text { vulgare) }\end{array}$} & $\begin{array}{l}\text { Croatia } \\
\text { (flowered } \\
\text { tops and } \\
\text { stalks) }\end{array}$ & $\begin{array}{c}\text { Thymol }(35.0 \%) \text {, carvacrol }(32.0 \%), \gamma \text {-terpinene } \\
(10.5 \%), p \text {-cymene }(9.1 \%), \alpha \text {-terpinene }(3.6 \%)\end{array}$ & $\begin{array}{c}\text { DPPH, } \mathrm{IC}_{50}=0.5 \mathrm{mg} / \mathrm{mL}(>\mathrm{BHT}, \mathrm{AA}, \text { and } \\
\alpha \text {-tocopherol, but }=\text { thymol }) ; \mathrm{TBARS} \\
\mathrm{AAI}=29.9 \%(<\mathrm{BHT}, \alpha \text {-tocopherol, } \\
\text { but }=\text { thymol and carvacrol })\end{array}$ & {$[169]$} \\
\hline & $\begin{array}{l}\text { Chile } \\
\text { (aerial parts) }\end{array}$ & $\begin{array}{c}\text { Thymol }(15.9 \%), Z \text {-sabinene hydrate }(13.4 \%), \\
\gamma \text {-terpinene }(10.6 \%), p \text {-cymene }(8.6 \%) \text {, linalyl } \\
\text { acetate }(7.2 \%) \text {, sabinene }(6.5 \%) \text {, carvacrol methyl } \\
\text { ether }(5.6 \%) \text {, carvacrol }(3.1 \%)\end{array}$ & $\begin{array}{c}\text { DPPH, } \mathrm{IC}_{50}=4.75 \mathrm{mg} / \mathrm{mL}(>\mathrm{Q} \text { and } \mathrm{TX}) \\
\text { ABTS, } 1252.7 \mu \mathrm{mol} \mathrm{TX} / \mathrm{g} ; \mathrm{FRAP} \\
270.5 \mu \mathrm{mol} \mathrm{TX} / \mathrm{g}\end{array}$ & {$[195]$} \\
\hline & $\begin{array}{c}\text { Algeria } \\
\text { (aerial parts) }\end{array}$ & $\begin{array}{c}p \text {-Cymene }(25.6 \%), \text { thymol }(23.1 \%), \text { carvacrol } \\
(20.3 \%), \gamma \text {-terpinene }(16.6 \%), \alpha \text {-terpinene }(1.8 \%)\end{array}$ & $\mathrm{DPPH}, \mathrm{IC}_{50}=0.461 \mathrm{mg} / \mathrm{mL}(>\mathrm{AA})$ & [166] \\
\hline \multirow{3}{*}{$\begin{array}{l}\text { White } \\
\text { wormwood } \\
\text { (Artemisia } \\
\text { herba-alba) }\end{array}$} & $\begin{array}{c}\text { Algeria } \\
\text { (aerial parts) }\end{array}$ & $\begin{array}{c}\text { Davanone D }(49.5 \%) \text {, camphor }(10 \%) \text {, } \\
\text { trans- } \gamma \text {-cadinene }(3.9 \%)\end{array}$ & $\begin{array}{c}\text { DPPH, } \mathrm{IC}_{50}=2.61 \mathrm{mg} / \mathrm{mL}(>\text { than } \mathrm{AA}) \\
\text { FRAP, } 8.17 \mu \mathrm{mol} \mathrm{TX} / \mathrm{g}(<\mathrm{AA}) ; \mathrm{ABTS} \\
6.74 \mu \mathrm{mol} \mathrm{TX} / \mathrm{g}(<\mathrm{AA})\end{array}$ & {$[192]$} \\
\hline & $\begin{array}{c}\text { Morocco } \\
\text { (aerial parts) }\end{array}$ & $\begin{array}{c}\beta \text {-Thujone }(42.9 \%), \text { chrysanthenone, } \alpha \text {-terpineol } \\
(9.7 \%), \alpha \text {-thujone }(5.4 \%), \alpha \text {-pinene }(4.6 \%), \text { bornyl } \\
\text { acetate }(2.4 \%)\end{array}$ & $\mathrm{DPPH}, \mathrm{IC}_{50}=2.9 \mu \mathrm{g} / \mathrm{mL}(>\mathrm{BHT})$ & {$[196]$} \\
\hline & $\begin{array}{c}\text { Tunisia } \\
\text { (aerial parts) }\end{array}$ & $\begin{array}{c}\alpha \text {-Thujone }(17.6 \%), \text { trans-sabinyl acetate }(17.2 \%), \\
\text { chrysanthenone }(8.3 \%), \beta \text {-thujone }(7.6 \%), \\
\text { germacrene } \mathrm{D}(7.0 \%)\end{array}$ & $\begin{array}{c}\text { DPPH, } \mathrm{IC}_{50}=1.17 \mathrm{mg} / \mathrm{mL}(>\mathrm{TX}) ; \mathrm{FRAP} \\
161.6 \mu \mathrm{mol} \mathrm{Fe} \mathrm{Fe}^{2+} / \mathrm{g} ; \mathrm{BCB}, 0.6 \mathrm{mg} / \mathrm{mL} \\
(>\mathrm{BHT})\end{array}$ & [197] \\
\hline
\end{tabular}

DPPH: 2,2-diphenyl-1-picrylhydrazyl; ABTS: 2,2'-azino-bis(3-ethylbenzothiazoline-6-sulfonic acid); BCB: $\beta$-carotene bleaching; FRAP: ferric reducing antioxidant power; TBARS: thiobarbituric acid-reactive species; FIC: ferrous ion-chelating; BCLA: $\beta$-carotene-linoleic acid assay; AAI: antioxidant activity index; TAC: total antioxidant capacity; RAA: relative antioxidant activity; TEAC: trolox equivalent antioxidant capacity; LAP: linoleic acid peroxidation; ROS: reactive oxygen species; DCFH: $2^{\prime}, 7^{\prime}$-dichlorofluorescin diacetate; BHA: butylated hydroxyanisole; BHT: butylated hydroxytoluene; AA: ascorbic acid; Q: quercetin; PG: propyl gallate.

Care should be taken before assuming that the antioxidant property of EOs is simply that of one characteristic component. Identifying a leading antioxidant compound and the elucidation of the exact mechanism of action is a herculean task due to the presence of a plethora of compounds with different molecular structures of antioxidant powers. However, EOs' chemical composition can allow to roughly predict its antioxidant potential, since it is expected that EOs containing higher amounts in phenolics and modest content in unsaturated terpenes display more robust antioxidant properties. One additional point 
should be considered concerning the antioxidant activity of EOs, and that is the enormous variability in chemical composition, even in EOs obtained from the same plant species, which hampers a direct comparison of published data. Such diversity is strictly connected to multiple factors, including geographic location, parts of the plant used, harvest time, environmental and agronomic conditions, phenological stage, and extraction methods [198].

Furthermore, synergistic or antagonistic effects could occur among the components, and such interactions may positively or negatively affect the ultimate antioxidant properties of EOs. For the aforementioned reasons, more in-depth knowledge of the mechanism of action and effects of individual compounds would allow the formulation of mixtures of compounds with optimized efficacy. Moreover, the vast amount of information being generated by in vitro assays requires further validation through systematic animal studies and clinical investigation.

\section{EOs and Rumen Fermentation}

EOs have been proposed for use in ruminant feed targeting different nutritional purposes and modulating the rumen's anaerobic fermentation processes. Microbial digestion in the rumen can be improved by using feed additives. Some additives could drive the fermentation reactions towards the formation of more efficient products by acting on the balance of the microbial population. Antibiotics have been widely used in the past as microbiota regulators. However, their use as feed additives has been banned in the EU since 2006. In this context, EOs could offer some new opportunities to replace antibiotics [199].

Some of the effects of EO can be indirectly related to EO activity on gut microbiota. Most of the studies have reported EO's effects on gut microbiota in pigs and poultry, whereas research on EOs' impact on ruminant microbiota is somehow lagging. Feeding pigs with a blend of oregano and cinnamon oil increased Lactobacillaceae and Ruminococcaceae and decreased Clostridiaceae in the intestine [200]. Firmicutes and Bacteroidetes were the two most dominant phyla in a study involving a mixture of EOs and organic acids in weaned piglets, which also induced an increase in performance [201]. Dietary supplementation with EO was associated with increased Lactobacilli and decreased coliforms in vivo [202]. Feeding thymol- and cinnamaldehyde-supplemented diets induced a decrease in E. coli carriage in piglets at a similar level to that obtained with in-feed antibiotics [203]. These results are mostly consistent using, in most cases, culture-related techniques. Introducing nextgeneration sequencing approaches to study EOs' impact on microbiota would probably provide more insights into the relationship between $\mathrm{EO}$ and the microbial community in the intestine and, in turn, how this relationship may shape the immune system. In poultry, treatment with $\mathrm{EO}$ has a synergistic effect with antibacterial peptides to reduce pathogenic intestinal microbiota's negative impact. Indeed, cecal microbiota composition can be substantially changed with either cinnamaldehyde alone or in combination with citral in the feed [204]. It is commonly found that EO may exhibit a potential antimicrobial activity against bacteria, archaea, protozoa, or fungi in the rumen [205]. Patra described EOs' potential to inhibit hyper-ammonia production bacteria, selective inhibition of Selenomonas ruminantium by thymol, and no substantial EO effects on ruminal ciliate protozoa. At high doses, EO can be highly inhibitory for most ruminal microorganisms [206].

However, other observations have shown that some compounds may not be inhibitory depending on the EO and the dose used. Using microarray analysis, Patra and Yu observed that some Firmicutes (especially Clostridia) and Butyrivibrio were decreased by EOs, whereas Bacteroidetes (Prevotella) were increased. However, the effects were highly dependent on the type of EO supplemented [207]. Oh and Hristov showed that dietary supplementation with oregano leaves in dairy cows decreased Ruminococcus flavefaciens, an important rumen fibrolytic bacteria [208]. However, Kim et al. observed an increase in several bacterial species (Selenomonas ruminantium, Ruminococcus albus, Butyrivibrio fibrisolvens, and Ruminococcus flavefaciens) and in fungi in response to an EO mixture [209]. Alagawany et al. reviewed the reported observations on effects of oregano and its main compounds (carvacrol, thymol) and found somewhat controversial effects. 
In most cases, a depressing impact on methanogen and fungal counts was reported [210]. Ruminal protozoa can also be reduced in response to EO activity [211,212]. Metagenomic analyses on the ruminal fluid from goats receiving EO-supplemented diets demonstrated ruminal microbiota changes in a dose-dependent way [213].

Considering the multiple effects of EO on rumen microbiota, it has been proposed that EOs could improve the feed efficiency and nutrient utilization in ruminants. EO can also decrease protein degradation in the rumen, whereas controversial effects on fiber degradation have been reported. In some cases, fiber degradation seems to be enhanced [212], whereas other studies have shown a decrease in the digestion of cell wall carbohydrates in the rumen. As a result, EO effects on the extent of degradation of feed in the rumen may be highly variable, depending on the source and type of EO, dose used, and methodology used in each study. Several studies have evaluated the effects of EO on ruminal fermentation in vitro. An increase in the culture medium's $\mathrm{pH}$ has been observed, although the difference observed depends on the EO added, the dose applied, and the buffer used in the medium. In general, $\mathrm{pH}$ is increased to a greater extent, with higher concentrations of phenols or cinnamaldehyde in the medium. This effect can be associated with the decrease in volatile fatty acid concentration in the medium, regardless of the EO tested. Although in some in vitro studies, a slight reduction in VFA production was observed when EO was added to the medium, other reports show little or no EO effect on VFA production or concentration. The VFA profile (molar proportion of each VFA) is a suitable indicator of any shift in the rumen fermentation pattern occurring in response to EO. Again, the literature results are highly diverging, although most commonly, effects showing a decrease in acetate and a trend to increase propionate and butyrate [212,214] have been reported. As a result, it is commonly observed that EO supplementation is related to a decrease in the acetate to propionate ratio in the rumen digesta [214,215]. Figure 5 summarizes the main effects of EOs in ruminal fermentation.

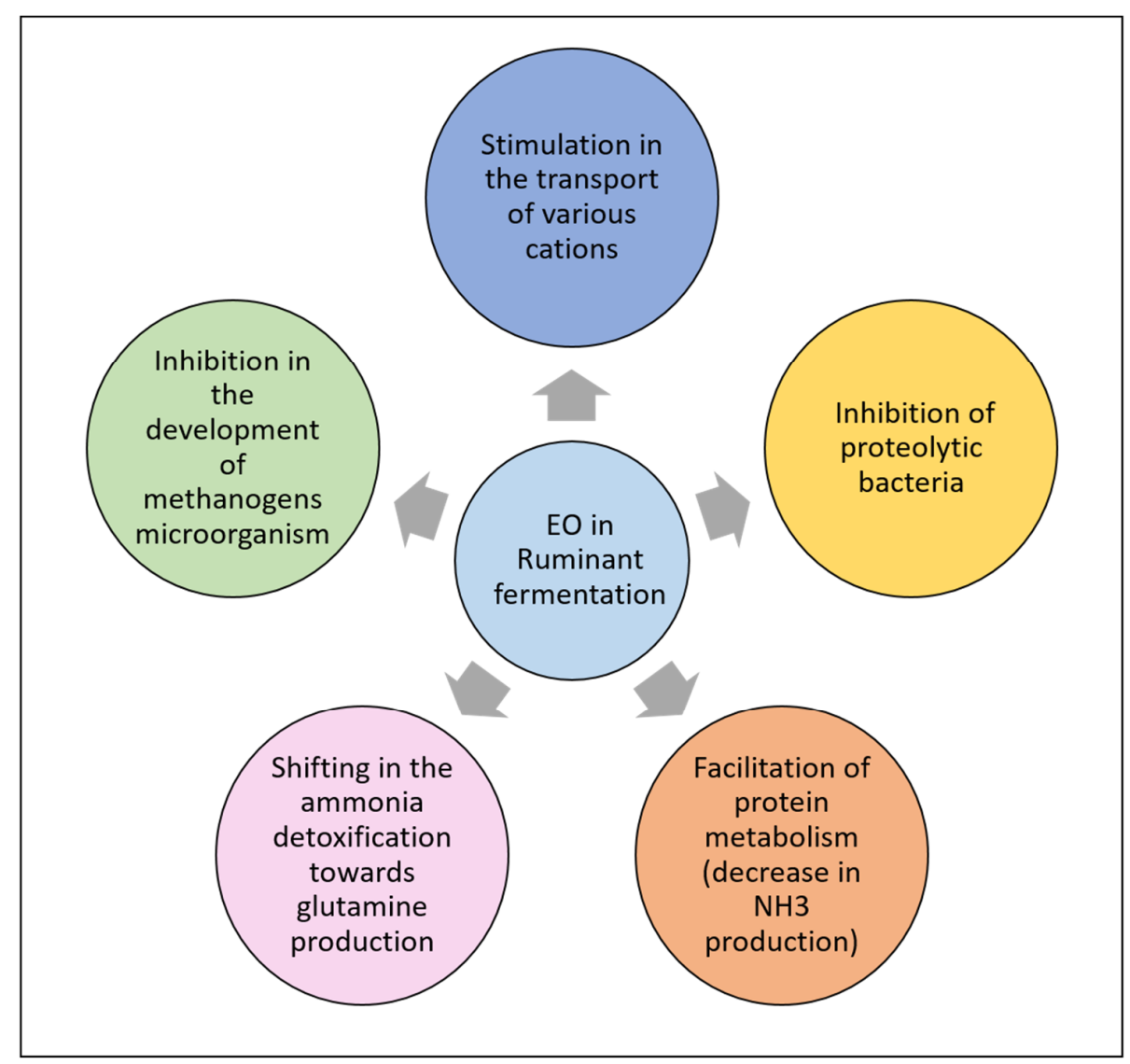

Figure 5. Essential oils in ruminant fermentation [216]. 
EOs may also affect the degradation and metabolism of feed proteins in the rumen by reducing the reactions of deamination of amino acids, thus decreasing ammonia production. In this sense, EOs could selectively prevent the proliferation of hyper-ammonia-producing bacteria, responsible for these reactions [217]. Only phenols and cinnamaldehyde decrease the concentration of ammonia-nitrogen $\left(\mathrm{N}-\mathrm{NH}_{3}\right)$ [218].

Due to its antimicrobial activity, a commonly recognized potential activity of EOs is the inhibiting effect on methanogenic archaea responsible for methane production. This is one of EOs' most widely recognized effects on ruminal fermentation and has been extensively explored (mainly in vitro) to reduce methane emissions from ruminants. Methane represents a loss of gross energy from feed and is considered a greenhouse gas. Thus, any reduction in methane derived from ruminal fermentation may enhance feed efficiency and reduce ruminant farming's environmental impact. Nevertheless, although the reducing effects on ruminal methanogenesis have been shown by several studies testing a diversity of EO $[216,219,220]$, some results are also questionable, as Jafari showed in his review on the effects of oregano, carvacrol, and thymol on ruminal methanogenesis [211].

Furthermore, EO can also affect some ruminal microorganisms involved in the biohydrogenation pathways, thus causing a modification of fatty acid profile/Polyunsaturated fatty acids (PUFAs) in ruminal digesta when EOs are fed to ruminants. Rosemary and thyme by-products seem to have a potential to increase the unsaturated FA content (particularly n-3 FA) in animal products due to their content in polyphenol compounds, which may inhibit targeted ruminal bacteria involved in biohydrogenation [221]. It must be considered, however, that different compounds and proportions are found in other EOs, blends, so to better describe the effects caused by these products at a ruminal level, it is desirable to carry out studies with pure compounds (e.g., carvacrol, thymol, eugenol) added at different levels, to better understand the modifications produced on ruminal microbiota and bio-hydrogenation pathways.

Summing up, the antimicrobial activity of some of the compounds contained in EO may affect the rumen microbiota. This may cause a shift in the ruminal fermentation pattern. Thus, in the derived digestion end-products that are either absorbed and used by the animal or disposed of as waste metabolites (methane or urea from ammonia), any effects of EO (at a given dose) must be the most selective as possible. Any broad and nonspecific activity will cause a general inhibition of ruminal fermentation with no beneficial impacts on the ruminant. Any success on any of the targeted activities may significantly impact animal metabolism, feed efficiency, product quality, and environmental impact. However, the literature results show that these effects are highly dependent on EO type, source, applied dose, and the mixture of EOs. Effects can also be transient due to an adaptation of the microbiota to survive EOs' antimicrobial effects. Thus, although results may suggest some tendencies, not entirely conclusive outcomes can be drawn from the available information. As an example, although effects from both carvacrol and thymol have been demonstrated in vitro, recently, the authors of Reference [222] have reported that no such effects on ruminal fermentation, animal productivity, and feed efficiency were observed in dairy cows in vivo.

\section{EOs in Animal Nutrition}

The effects of EOs, when supplied in the feed on the meat and milk quality of the animal, are contradictory, probably due to the different compositions of the EOs administered in each study. However, there is a consensus that low doses of EOs when feeding between 1.33 and $4 \mathrm{~g} /$ animal/day, may improve, in some cases, meat quality and shelf life (lessened color degradation, increased antioxidant activity, and decreased lipid oxidation in the meat). A dose of $3.5 \mathrm{~g} / \mathrm{animal} /$ day could be recommended in feedlot animals [223,224]. These low doses have shown some antioxidant activity, which may reduce the lipid peroxidation of meat (and improve color) and the oxidation proteases such as calpain, thus enhancing the tenderness of meat [225]. 
An extensive review describing the mechanisms of actions of EOs to improve meat quality of lambs has been recently published by Garcia-Galicia et al. [226].

However, greater doses could have a pro-oxidant effect on the animal, with detrimental consequences on health status and product quality. This is because high doses of EO can permeabilize the mitochondria, thus changing electrons' flow and producing more free radicals, such as reactive oxygen species (ROS) that oxidize lipids and proteins. Some metabolites might be accumulated at the meat level, since supplementing lambs with rosemary EOs improved the sensory properties of lamb's meat (e.g., flavor and overall acceptability were increased) [221]. However, it is interesting to note that most of the studies published describing the effects of EOs on meat quality when being fed to animals do not evaluate the transmission of metabolites/compounds to the product, which can be different according to the absorption distribution metabolism and excretion (ADME) of the various components included in the composition of the EO administered. Therefore, many of these studies cannot attribute the effects observed in meat quality to direct or indirect effects caused by the different compounds of EOs at the meat level. This approach should be addressed in the future for a better comprehension of the mechanisms of action unchained by EOs at the meat level.

Similar doses of EOs have been suggested when feeding dairy ruminants to improve feed efficiency and milk quality. For example, Al-Suwaiegh et al. have recently described improvements in milk yield, milk total bacterial count, milk somatic cell count, and feed efficiency when feeding the lowest dose ( $2.5 \mathrm{~g} /$ head/day vs $5 \mathrm{~g} /$ head/day) of an EOs blend of clove, oregano, and juniper in equal proportions to early lactating Holstein dairy cows. They attributed these effects, at least partially, to lack of inhibition of the rumen microbial populations by the lowest EO dose [227].

A recent study done by El-Essawy et al. evaluated the effect of a mixture of EOs (anise, clove, and thyme) on eight lactating shame goats. Supplementation of these EOs improved digestibility with no effect on intake and milk yield. They found that EOs' supplementation improved the fermentation (digestibility of organic matter, ether extract, and acid detergent fiber was higher). Adding the EO increased milk fat yield, fat content, and the concentrations of unsaturated and monounsaturated fatty acids (FA) compared with the control diet [228]. Benchaar found that dairy cows' feed added with Thymus EO failed to improve the fermentation [222]. Soltan et al. studied the effect of a microencapsulated mixture of EOs containing cinnamaldehyde, eugenol, carvacrol, and capsicum oleoresin on Santa Inês sheep. They found that the feed implementation of this mixture decreases methane production [229].

Adding EOs to animal feed could affect the quality of fat in milk and meat, by inhibiting bacteria responsible for the bio-hydrogenation of unsaturated fat. It was also proven that supplementation in anise, nails clove, and juniper EOs improves the concentration of Conjugated Linoleic Acids and omega 3 in dairy goats [230]. Kholif et al. demonstrated that adding Capsicum and Thymus EO with fibrolytic enzyme (obtained from Aspergillus niger) to Farafra ewes' feeding increased the milk production, the feed efficiency, and the fat content in the milk. This mixture enhances the fiber digestibility by increasing the number of cellulolytic bacteria, causing an increase in the fat quantity. It also minimizes the energy and protein losses, causing an increase in milk production [231].

\section{EOs in Food Products}

To enhance the shelf life of food products and conserve their sensory characteristics, EOs could be added directly to food or in active food packaging. Researchers have been studying this phenomenon for years, and they have proven its effectiveness in vegetables, fish, dairy products, poultry, and beef packages. The EO is incorporated into a polymer matrix which is used to pack food. The migration of EO into food was studied to ensure the sensory stability of the food product. Table 4 lists five recent studies where the EOs were used in the food packaging. 
Table 4. Five selected bibliographical studies showing the beneficial use of EOs in different food packaging.

\begin{tabular}{|c|c|c|c|c|}
\hline EO & Polymer & Food & Results & Reference \\
\hline $\begin{array}{l}\text { Laurus nobilis and } \\
\text { Rosmarinus officinalis }\end{array}$ & Polyvinyl alcohol & $\begin{array}{l}\text { Chicken } \\
\text { breast fillets }\end{array}$ & $\begin{array}{l}\text { Inhibition of the lipid oxidation up to } \\
68 \% \text {. Beneficial effect on both the } \mathrm{pH} \\
\text { and color parameters of the fillets } \\
\text { during storage. }\end{array}$ & [232] \\
\hline $\begin{array}{l}\text { Rosemary and } \\
\text { cinnamon EO }\end{array}$ & Polyethylene films & $\begin{array}{c}\text { Pacific } \\
\text { white shrimp }\end{array}$ & $\begin{array}{l}\text { Prolonged and retained shrimp } \\
\text { freshness and shelf life }\end{array}$ & [233] \\
\hline $\begin{array}{l}\text { Carvacrol, oregano, } \\
\text { and cinnamon }\end{array}$ & Cardboard tray & Cherry tomato & $\begin{array}{l}\text { Tomato color and firmness were highly } \\
\text { maintained during storage. The shelf } \\
\text { life was extended up to } 4 \text { days }\end{array}$ & [234] \\
\hline Cumin EO & $\begin{array}{l}\text { Shahri Balangu } \\
\text { seed mucilage }\end{array}$ & Beef & Expand the shelf life of the beef & [235] \\
\hline Oregano & $\begin{array}{l}\text { Edible coating: mandarin } \\
\text { fiber and sodium alginate }\end{array}$ & Low-fat cheese & $\begin{array}{l}\text { Decontamination of external pathogens } \\
\text { such as Staphylococcus aureus }\end{array}$ & [236] \\
\hline
\end{tabular}

Several papers have demonstrated the inhibitory effect of EOs to extend the shelf life of beef burgers by controlling the proliferation of pathogenic bacteria through antimicrobial activity. This is due to hydroxyl groups' presence in phenolic compounds (e.g., thymol, eugenol, carvacrol) which can degrade the bacterial cell wall, disturbing the phospholipid bilayer of the cytoplasmic membrane, causing leakage and cell death. They can further disrupt the proton motive force, electron flow, and active transport, coagulate the cell contents, impair enzymes involved in the energy regulation and synthesis of structural components [147], or inactivate or destroy genetic material, increasing the EOs' antimicrobial activities.

Meat and poultry products are also sensitive to oxidation. This process leads to the deterioration of odor, color, and flavors in these products [237]. Adding EOs to the meat products enhances their shelf life by inhibiting their oxidation: Adding rosemary EO on frankfurters significantly decreases the number of carbonyls originated from protein. It also reduces the color change, hardness, chewiness, and frankfurters' adhesiveness during storage in a fridge [238]. Another study shows that Thymbra spicata EO was more effective than synthetic antioxidants on Turkish dry-fermented sausage [239]. Adding oregano EO in salchichon (fermented dry Spanish sausages) led to an increase in the quantity of unsaturated fatty acids without affecting the lipolysis process or the final product's sensory attributes [240].

However, this beneficial activity of EOs when added to meat can be reduced when there is a high content of fat, for example [241]. An extensive review of the antimicrobial effects of EOs when added to meat was published by Pateiro et al. [242], compiling the different extraction protocols for EOs.

EOs could be added to edible oils and fat to block unsaturated oils' oxidative reaction, causing unpleasant taste and flavor production. The oxidation of fat could also produce some toxic compounds, such as aliphatic and aromatic ketones, carboxylic acids, aldehydes, esters, sulfoxides, phenols, anhydrides, quinones, and aliphatic and aromatic alcohols [243]. Adding oregano EO in a combination of saturated and unsaturated fatty acids inhibited the oxidation process in the presence of light for one year [244]. The same results were observed when blackseed EO (Nigella sativa L.) was added to sunflower oil [203], clove and thyme EOs to cottonseed oil [245], and zenyan EO to mayonnaise [246].

EOs could also be added in dairy products: (i) Adding Thymus capitatus EO to raw milk could improve its pasteurization and improve its conservation by delaying its spoilage [247]. (ii) The incorporation of $250 \mu \mathrm{L} / \mathrm{kg}$ of EO such as cinnamon, clove, and rosemary in concentrated yoghurt could also increase the product's shelf life [248]. (iii) EOs could also be added to ice cream: Adding lemon peel and lavender EOs inhibits the development of 
Salmonella, E. coli, Listeria, and S. Aureus [249]. (iv) Thymus and cumin EOs could be added to butter to prevent its deterioration during room-temperature storage [250].

\section{Conclusions}

The health status of animals and the quality of the final products are heavily affected by the adverse effects caused by the oxidative stress [16,251,252]. EOs isolated from plants display biological properties with antioxidant, anti-inflammatory, and antimicrobial activities $[115,156]$, leading to environmentally friendly technologies and limiting antimicrobial resistance. Their robust antioxidant properties can be attributed, at least in part, to their richness in terms of phenolic derivatives acting by preventing lipid peroxidation, scavenging free radicals, or, and in very few cases, chelating metal ions [156,157].

Due to the rising concerns on the safety of their long-term consumption, EOs as food additives protecting against foodborne pathogens have come to the forefront of this field of research. Moreover, chemical preservatives cannot eliminate several pathogenic bacteria on food products, such as Listeria monocytogenes, or delay the growth of spoilage microorganisms. EOs may play that role. They are also environmentally friendly and have the advantage of being better tolerated in the human body, usually with fewer side effects [10].

Effectiveness of EOs in extending the shelf life and oxidative stability of dairy and meat products was proven [147]. However, some issues are raised. EOs can negatively alter the product's organoleptic properties due to their intense aroma, which may affect the consumer acceptability [253]. Moreover, the possible interaction between EOs' components and constituents, such as fats, carbohydrates, protein, and salts, should be considered. These reactions may reduce the antioxidant activity of these natural products [147]. The synergistic effect of the combination of different EOs could address this issue since it allows lower concentrations of EOs combined with other compounds, thus enhancing their antioxidant effect.

Using EOs to promote animal health and welfare from a One Health perspective is very important (Figure 6). Studies in controlled conditions mostly agree that EOs affect the immune system by activating the arachidonic metabolism or cytokine production and/or the modulation of pro-inflammatory gene expression by regulating the NF- $\mathrm{kB}$ inflammatory pathway and MAPK signaling pathway [136]. Macrophage phagocytosis and oxidative burst have also been considered as additional potential mechanisms modulated by the action of EOs [137]. Nevertheless, the effects were mostly demonstrated under in vitro conditions. More well-designed in vitro and in vivo studies, involving a normalization of dose, taking into account environmental factors such as the type of the diet, breed, and age, will allow a better understanding of EOs' biological activities under several environmental conditions. In addition, the activities' molecular bases have not been primarily investigated in depth in this field and may change depending on the specific EO used and the type and severity of the disease. Thus, considering the multitude of components of EOs and the spectrum of possible activities, there is still a vast amount unknown about their actual effects on animal health and particularly in ruminants.

Emerging studies in cattle indicate an improvement in ruminant performance and feed efficiency when EOs are given in the diet $[228,230,231]$, which may add perspective in using EOs in animal nutrition. These positive effects might be partially due to the modulation exerted on the ruminal microbiota, increasing the fiber's digestibility to produce volatile fatty acids and synthesize microbial protein as an energy and protein supply ruminant, respectively $[254,255]$. Recent studies with thymol supplementation contrasted with the claimed in vitro antimicrobial activity of EOs: no positive effects on rumen metabolism (i.e., $\mathrm{N}$ and VFA) nor beneficial effects on rumen fermentation, nutrient utilization, and milk performance in dairy cows were observed, indicating the complexity of each EO effect per se. Care should be taken before assuming that the property of EOs is simply that of one characteristic component. Identifying a leading beneficial compound and the elucidation of the exact mechanism of action is complicated due to a plethora of compounds with different molecular structures, and antioxidant and antimicrobial activities. More in-depth 
knowledge of the mechanism of action and effects of individual compounds would allow the formulation of compounds with optimized efficacy and EOs' inclusion in the diet.

\section{Reduced antimicrobial and antimicrobial resistance}

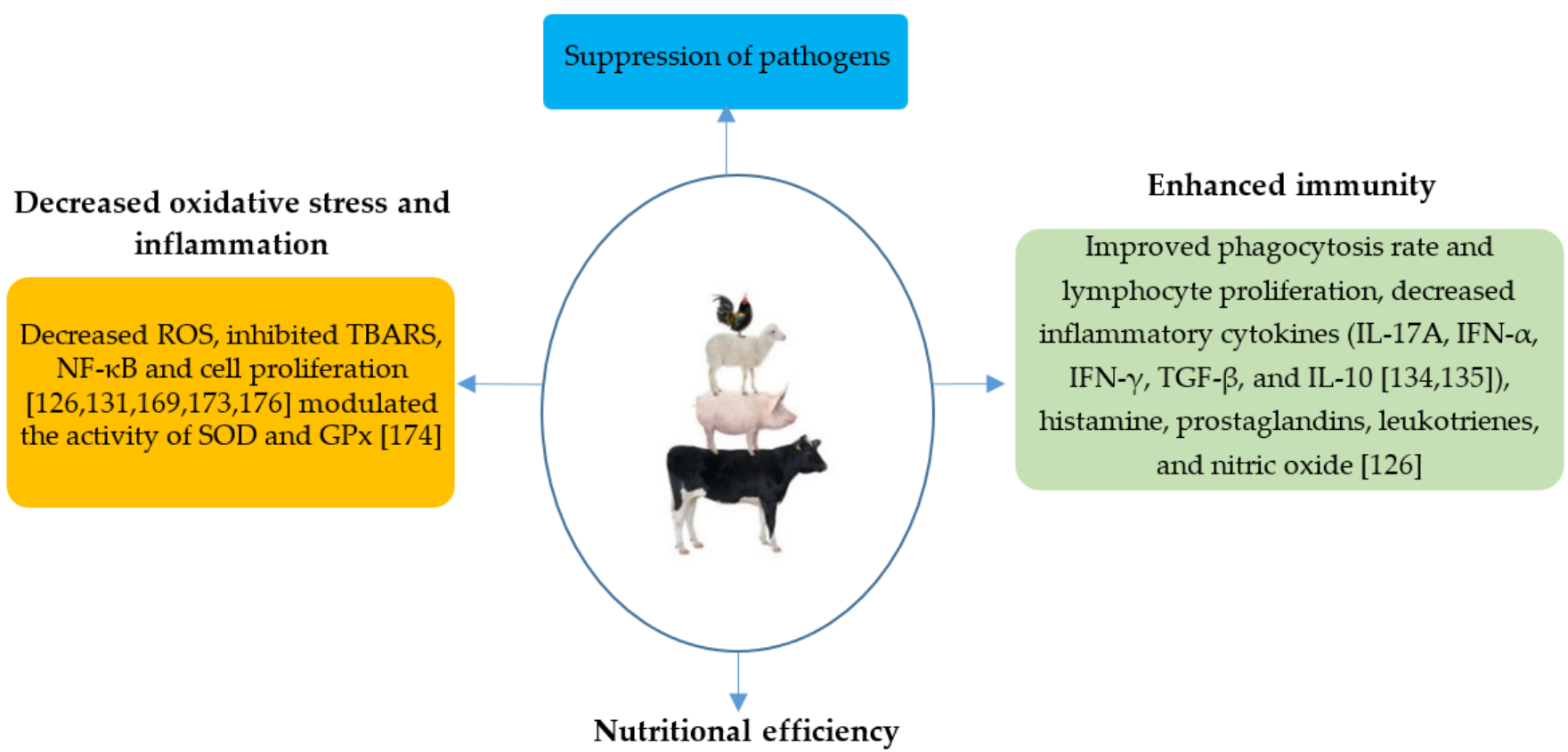

Changes in animal microbiota $[200-202,204]$

Figure 6. EOs in livestock from a One Health perspective. IL: Interleukin; NF-kB: Nuclear Factor Kappa B; TGF- $\beta$ : Transforming growth factor-beta; IFN: Interferon; GPx: Glutathione peroxidase; SOD: superoxide dismutase; ROS: Reactive oxygen species, TBARS: Thiobarbituric acid-reactive species.

Given the plasticity of the gut and the $\mathrm{DOHaD}$ concept's microbiome, the potential use of EOs in early nutrition programs (gestation and lactation) would be worthwhile. Early EO supplementation may improve the immunity responses with beneficial effects in feed efficiency and later-life performance [256-258]. This strategy might be considerably relevant. It can reduce both the administration time (limited only to the first two months of life instead of during the lactation) and the dose needed to positively affect calves at adult age. A reduction in the total cost of the treatment might be expected. However, attention should be paid regarding the doses given to the fetus and newborn due to the unknown potential toxicity effects of EOs when given during early life.

In summary, our review identified EOs as a potential future therapeutic option in both ruminant and monogastric husbandries. EOs are unlikely to replace antimicrobials, but they can at least be used as a complementary treatment. The results of this review provide support for a need for additional in vitro and in vivo research focused on EOs as antioxidant, anti-inflammatory, and antimicrobial agents for recently emerging and challenging diseases in livestock and to improve animal-derived products. While many peer-reviewed studies about EOs were performed in humans and experimental models, more research is needed to evaluate the potential of EOs for the treatment of farm animals.

Regarding feeding, hygiene, and conservation, EOs are part of a sustainable, natural option for improving animal health and animal product-derived food, reducing the use of antimicrobials in livestock farming.

We hope that the present review will stimulate further in vitro and in vivo research focused on EOs' effects among livestock management practice and diseases prevention, opening new avenues in this field and providing guidance on EOs as new challenging molecules in livestock. 
Author Contributions: Conceptualization, L.A.-N.; writing-original draft preparation, R.N. and L.A.-N.; writing-review and editing: R.N., S.A., M.B.J., R.B.P., S.B., F.C., S.L., F.Z.R., R.K., D.M.P., and L.A.-N. All authors have read and agreed to the published version of the manuscript.

Funding: This research was funded under H2020-PRIMA 2018-Section 2.

Acknowledgments: The authors gratefully acknowledge Florence Macherez for her assistance during the conception of the work and Eva Drouin for bibliometrics.

Conflicts of Interest: The authors declare no conflict of interest.

$\begin{array}{ll}\text { Abbreviations } \\ \text { EOs } & \text { Essential oils } \\ \text { EO } & \text { Essential oil } \\ \text { LPS } & \text { Lipopolysaccharides } \\ \text { DPPH } & \text { 2,2-diphenyl-1-picrylhydrazyl } \\ \text { BCB } & \beta \text {-carotene bleaching } \\ \text { FRAP } & \text { Ferric-reducing antioxidant power } \\ \text { TBARS } & \text { Thiobarbituric acid-reactive species } \\ \text { FIC } & \text { Ferrous ion-chelating } \\ \text { BCLA } & \beta \text {-carotene-linoleic acid assay } \\ \text { AAI } & \text { Antioxidant activity index } \\ \text { TAC } & \text { Total antioxidant capacity } \\ \text { RAA } & \text { Relative antioxidant activity } \\ \text { TEAC } & \text { Trolox equivalent antioxidant capacity } \\ \text { LAP } & \text { Linoleic acid peroxidation } \\ \text { DCFH } & \text { 2',7'-dichloro-fluorescin-diacetate } \\ \text { BHA } & \text { Butylated hydroxyanisole } \\ \text { BHT } & \text { Butylated hydroxytoluene } \\ \text { AA } & \text { Ascorbic acid } \\ \text { Q } & \text { Quercetin } \\ \text { PG } & \text { propyl gallate } \\ \text { TNF- } \alpha & \text { Tumor necrosis factor- } \alpha \\ \text { IL } & \text { Interleukin } \\ \text { DAO } & \text { Diamine oxidase } \\ \text { Ig } & \text { Immunoglobulin } \\ \text { ZO-1 } & \text { Zonula occludens-1 } \\ \text { NF- } \text { B } & \text { Nuclear Factor Kappa B } \\ \text { BAX } & \text { Bcl-2 Associate } X \text { protein } \\ \text { TGF- } \beta & \text { Transforming growth factor beta } \\ \text { IFN } & \text { Interferon } \\ \text { GPx } & \text { Glutathione peroxidase } \\ \text { SOD } & \text { superoxide dismutase } \\ \text { ROS } & \text { Reactive oxygen species } \\ \text { FA } & \text { fatty acids } \\ \text { ADME } & \text { absorption distribution metabolism and excretion } \\ \text { IC } 50 & \text { The half maximal inhibitory concentration } \\ & \end{array}$

\section{References}

1. Lesage, M. Les Antibiorésistances en Élevage: Vers des Solutions Intégrées. MONTREUIL SOUS BOIS. Available online: https://agriculture.gouv.fr/sites/minagri/files/cep_analyse82_antibioresistances_en_elevage.pdf (accessed on 13 January 2021).

2. Wall, B.A.; Mateus, A.L.P.; Marshall, L.; Pfeiffer, D.U.; Lubroth, J.; Ormel, H.J.; Otto, P.; Patriarchi, A. Drivers, Dynamics and Epidemiology of Antimicrobial Resistance in Animal Production; Food and Agriculture Organization of the United Nations: Rome, Italy, 2016; Available online: http:/ / www.fao.org/publications/card/fr/c/d5f6d40d-ef08-4fcc-866b-5e5a92a12dbf/ (accessed on 14 February 2021).

3. Goossens, H.; Ferech, M.; Vander Stichele, R.; Elseviers, M. Outpatient antibiotic use in Europe and association with resistance: A cross-national database study. Lancet 2005, 365, 579-587. [CrossRef]

4. Hu, Y.; Gao, G.F.; Zhu, B. The antibiotic resistome: Gene flow in environments, animals and human beings. Front. Med. 2017, 11, 161-168. [CrossRef] 
5. Forsberg, K.J.; Reyes, A.; Wang, B.; Selleck, E.M.; Sommer, M.O.; Dantas, G. The shared antibiotic resistome of soil bacteria and human pathogens. Science 2012, 337, 1107-1111. [CrossRef]

6. Simitzis, P.E. Enrichment of Animal Diets with Essential Oils-A Great Perspective on Improving Animal Performance and Quality Characteristics of the Derived Products. Medicines 2017, 4, 35. [CrossRef] [PubMed]

7. Mushtaq, S.; Shah, A.M.; Shah, A.; Lone, S.A.; Hussain, A.; Hassan, Q.P.; Ali, M.N. Bovine mastitis: An appraisal of its alternative herbal cure. Microb. Pathog. 2018, 114, 357-361. [CrossRef]

8. Jean, B. Pharmacognosy Phytochemistry, Medicinal Plants, 2nd ed; Lavoisier: Paris, France, 2008; Volume 934.

9. Brenes, A.; Roura, E. Essential oils in poultry nutrition: Main effects and modes of action. Anim. Feed Sci. Technol. 2010, 158, 1-14. [CrossRef]

10. Liu, Q.; Meng, X.; Li, Y.; Zhao, C.-N.; Tang, G.-Y.; Li, H.-B. Antibacterial and Antifungal Activities of Spices. Int. J. Mol. Sci. 2017, 18, 1283. [CrossRef]

11. Gutierrez, J.; Barry-Ryan, C.; Bourke, P. Antimicrobial activity of plant essential oils using food model media: Efficacy, synergistic potential and interactions with food components. Food Microbiol. 2009, 26, 142-150. [CrossRef]

12. Shi, C.; Zhang, X.; Zhao, X.; Meng, R.; Liu, Z.; Chen, X.; Guo, N. Synergistic interactions of nisin in combination with cinnamaldehyde against Staphylococcus aureus in pasteurized milk. Food Control 2017, 71, 10-16. [CrossRef]

13. Fernandes RV de, B.; Guimarães, I.C.; Ferreira, C.L.R.; Botrel, D.A.; Borges, S.V.; de Souza, A.U. Microencapsulated Rosemary (Rosmarinus officinalis) Essential Oil as a Biopreservative in Minas Frescal Cheese. J. Food Process. Preserv. 2017, 41, e12759. [CrossRef]

14. Moro, A.; Librán, C.M.; Berruga, M.I.; Carmona, M.; Zalacain, A. Dairy matrix effect on the transference of rosemary (Rosmarinus officinalis) essential oil compounds during cheese making. J. Sci. Food Agric. 2015, 95, 1507-1513. [CrossRef] [PubMed]

15. Lykkesfeldt, J.; Svendsen, O. (2007, May). Oxidants and antioxidants in disease: Oxidative stress in farm animals. Vet. J. 2007, 173, 502-511. [CrossRef]

16. Castillo, C.; Hernandez, J.; Bravo, A.; Lopez-Alonso, M.; Pereira, V.; Benedito, J.L. Oxidative status during late pregnancy and early lactation in dairy cows. Vet. J. 2005, 169, 286-292. [CrossRef]

17. Jang, I.S.; Ko, Y.H.; Kang, S.Y.; Lee, C.Y. Effect of a commercial essential oil on growth performance, digestive enzyme activity and intestinal microflora population in broiler chickens. Anim. Feed Sci. Technol. 2007, 134, 304-315. [CrossRef]

18. Cetin, E.; Yibar, A.; Yesilbag, D.; Cetin, I.; Cengiz, S.S. The effect of volatile oil mixtures on the performance and ilio-caecal microflora of broiler chickens. Br. Poult. Sci. 2016, 57, 780-787. [CrossRef]

19. Adaszýnska-Skwirzýnska, M.; Szczerbínska, D. The effect of lavender (Lavandula angustifolia) essential oil as a drinking water supplement on the production performance, blood biochemical parameters, and ileal microflora in broiler chickens. Poult. Sci. 2019, 98, 358-365. [CrossRef]

20. Zeng, Z.; Xu, X.; Zhang, Q.; Li, P.; Zhao, P.; Li, Q.; Liu, J.; Piao, X. Effects of essential oil supplementation of a low-energy diet on performance, intestinal morphology and microflora, immune properties and antioxidant activities in weaned pigs. Anim. Sci. J. 2015, 86, 279-285. [CrossRef] [PubMed]

21. Li, S.Y.; Ru, Y.J.; Liu, M.; Xu, B.; Péron, A.; Shi, X.G. The effect of essential oils on performance, immunity and gut microbial population in weaner pigs. Livest. Sci. 2012, 145, 119-123. [CrossRef]

22. Omonijo, F.A.; Ni, L.; Gong, J.; Wang, Q.; Lahaye, L.; Yang, C. Essential oils as alternatives to antibiotics in swine production. Anim. Nutr. 2018, 4, 126-136. [CrossRef]

23. Barker, D.J.P.; Osmond, C. Infant mortality, childhood nutrition, and ischaemic heart disease in england and wales. Lancet 1986, 327, 1077-1081. [CrossRef]

24. Boyle, W. Spices and Essential Oils as Presservatives. In The American Perfumer and Essential Oil Review 66; 1955; pp. 25-28. Available online: https:/ / www.scirp.org/(S(351jmbntvnsjt1aadkposzje))/ reference/ReferencesPapers.aspx?ReferenceID=902045 (accessed on 30 January 2021).

25. Luebbe, K.M.; Stalker, L.A.; Klopfenstein, T.J.; Funston, R.N. Influence of weaning date and late gestation supplementation on beef system productivity I: Animal performance. Transl. Anim. Sci. 2019, 3, 1492-1501. [CrossRef]

26. Funston, R.N.; Summers, A.F. Effect of prenatal programming on heifer development. Vet. Clin. Food Anim. Pract. 2013, 29, 517-536. [CrossRef] [PubMed]

27. Bakkali, F.; Averbeck, S.; Averbeck, D.; Idaomar, M. Biological effects of essential oils-A review. Food Chem. Toxicol. 2008, 46, 446-475. [CrossRef]

28. Kasaian, J.; Asili, J.; Iranshahi, M. Sulphur-containing compounds in the essential oil of Ferula alliacea roots and their mass spectral fragmentation patterns. Pharm. Biol. 2016, 54, 2264-2268. [CrossRef]

29. Guenther, E. The Essential Oils; D. Van Nostrand: New York, NY, USA, 1948.

30. Van de Braak, S.A.A.J.; Leijten, G.C.J.J. Essential Oils and Oleoresins: A Survey in the Netherlands and other Major Markets in the European Union; CBI, Centre for the Promotion of Imports from Developing Countries: Rotterdam, The Netherlands, $1999 ;$ p. 116.

31. Shelef, L.A.; Jyothi, E.K.; Bulgarellii, M.A. Growth of Enteropathogenic and Spoilage Bacteria in Sage-Containing Broth and Foods. J. Food Sci. 1984, 49, 737-740. [CrossRef]

32. Nychas, G.J.E. Natural antimicrobials from plants. In New Methods of Food Preservation; Gould, G.W., Ed.; Blackie Academic and Professional: London, UK, 1995; pp. 58-89. [CrossRef] 
33. Tuley de Silva, K. A Manual on the Essential Oil Industry; United Nations Industrial Development Organization, Vienna, Austria, 1996.

34. Mari, M.; Bertolini, P.; Pratella, G.C. Non-conventional methods for the control of post-harvest pear diseases. J. Appl. Microbiol. 2003, 94, 761-766. [CrossRef]

35. Ultee, A.; Smid, E.J. Influence of carvacrol on growth and toxin production by Bacillus cereus. Int. J. Food Microbiol. 2001, 64, 373-378. [CrossRef]

36. Juglal, S.; Govinden, R.; Odhav, B. Spice oils for the control of co-occurring mycotoxin-producing fungi. J. Food Prot. 2002, 65, 683-687. [CrossRef]

37. Pandey, R.; Kalra, A.; Tandon, S.; Mehrotra, N.; Singh, H.N.; Kumar, S. Essential Oils as Potent Source of Nematicidal Compounds. J. Phytopathol. 2000, 148, 501-502. [CrossRef]

38. Pessoa, L.M.; Morais, S.M.; Bevilaqua, C.M.L.; Luciano, J.H.S. Anthelmintic activity of essential oil of Ocimum gratissimum Linn. and eugenol against Haemonchus contortus. Vet. Parasitol. 2002, 109, 59-63. [CrossRef]

39. Konstantopoulou, I.; Vassilopoulou, L.; Mavragani-Tsipidou, P.; Scouras, Z.G. Insecticidal effects of essential oils. A study of the effects of essential oils extracted from eleven Greek aromatic plants on Drosophila auraria. Experientia 1992, 48, 616-619. [CrossRef]

40. Karpouhtsis, I.; Pardali, E.; Feggou, E.; Kokkini, S.; Scouras, Z.G.; Mavragani-Tsipidou, P. Insecticidal and Genotoxic Activities of Oregano Essential Oils. J. Agric. Food Chem. 1998, 46, 1111-1115. [CrossRef]

41. Mahmoud, S.S.; Croteau, R.B. Strategies for transgenic manipulation of monoterpene biosynthesis in plants. Trends Plant Sci. 2002, 7, 366-373. [CrossRef]

42. Bauer, K.; Garbe, D.; Surburg, H. Common Fragrance and Flavor Materials: Preparation, Properties and Uses; Wiley-VCH: Weinheim, Germany, 2001; p. 293.

43. Crosthwaite, D. UK trade within the flavour and fragrance industry. In Proceedings of the International Federation of Essential Oils and Aroma Trades-21st International Conference on Essential Oils and Aroma's 1998; IFEAT: London, UK, $1998 ;$ pp. 6-12.

44. Carson, C.F.; Riley, T.V. Antimicrobial activity of the essential oil of Melaleuca alternifolia. Lett. Appl. Microbiol. 1993, 16, 49-55. [CrossRef]

45. KBauer und, D. Garbe: Common Fragrance and Flavour Materials: Preparation, Properties and Uses; John Wiley \& Sons: Weinheim, Germany, 2008. [CrossRef]

46. Oosterhaven, K.; Poolman, B.; Smid, E.J. S-carvone as a natural potato sprout inhibiting, fungistatic and bacteristatic compound. Ind. Crop. Prod. 1995, 4, 23-31. [CrossRef]

47. Manabe, A.; Nakayama, S.; Sakamoto, K. Effects of Essential Oils on Erythrocytes and Hepatocytes from Rats and Dipalmitoyl Phosphatidylcholine-Liposomes. Jpn. J. Pharmacol. 1987, 44, 77-84. [CrossRef]

48. Bauer, K.; Garbe, D.; Surburg, H. Common Fragrance and Flavor Materials: Preparation, Properties and Uses, 3rd ed.; John Wiley \& Sons: Weinheim, Germany, 2008; Available online: https:/ /www.wiley.com/en-us/Common+Fragrance+and+Flavor+Materials\%3A+ Preparation\%2C+Properties+and+Uses\%2C+3rd+Edition-p-9783527612376 (accessed on 1 February 2021).

49. Cox, S.D.; Mann, C.M.; Markham, J.L.; Bell, H.C.; Gustafson, J.E.; Warmington, J.R.; Wyllie, S.G. The mode of antimicrobial action of the essential oil of Melaleuca alternifolia (Tea tree oil). J. Appl. Microbiol. 2000, 88, 170-175. [CrossRef] [PubMed]

50. Van Krimpen, M.M.; Binnendijk, G. RopadiarR as alter252 S. Burt. International Journal of Food Microbiology $94,223-253$. Retrieved from native for antimicrobial growth promoter in diets of weanling pigs. Lelystad, Praktijkonderzoek Veehouderij. May 2001; ISSN 0169-3689. p. 14.

51. Ilsley, S.; Miller, H.; Greathead, H.; Kamel, C. Herbal sow diets boost pre-weaning growth. Pig Progress 2002, 18, 8-10.

52. Mendoza-Yepes, M.J.; Sanchez-Hidalgo, L.E.; Maertens, G.; Marin-Iniesta, F. Inhibition Of Listeria Monocytogenes And Other Bacteria By A Plant Essential Oil (Dmc) In Spanish Soft Cheese. J. Food Saf. 1997, 17, 47-55. [CrossRef]

53. Cutter, C.N. Antimicrobial effect of herb extracts against Escherichia coli O157:H7, Listeria monocytogenes, and Salmonella Typhimurium associated with beef. J. Food Prot. 2000, 63, 601-607. [CrossRef]

54. Řebíčková, K.; Bajer, T.; Šilha, D.; Ventura, K.; Bajerová, P. Comparison of Chemical Composition and Biological Properties of Essential Oils Obtained by Hydrodistillation and Steam Distillation of Laurus nobilis L. Plant Foods Hum. Nutr. 2020, 75, 495-504. [CrossRef]

55. El Asbahani, A.; Miladi, K.; Badri, W.; Sala, M.; Addi, E.H.A.; Casabianca, H.; El Mousadik, A.; Hartmann, D.; Jilale, A.; Renaud, F.N.R.; et al. Essential oils: From extraction to encapsulation. Int. J. Pharm. 2009, 483, 220-243. [CrossRef] [PubMed]

56. Bousbia, N.; Abert Vian, M.; Ferhat, M.A.; Petitcolas, E.; Meklati, B.Y.; Chemat, F. Comparison of two isolation methods for essential oil from rosemary leaves: Hydrodistillation and microwave hydrodiffusion and gravity. Food Chem. 2009, 114, 355-362. [CrossRef]

57. Özel, M.Z.; Göğüş, F.; Lewis, A.C. Comparison of direct thermal desorption with water distillation and superheated water extraction for the analysis of volatile components of Rosa damascena Mill. using GCxGC-TOF/MS. Anal. Chim. Acta 2006, 566, 172-177. [CrossRef]

58. Aziz, Z.A.; Ahmad, A.; Setapar, S.H.M.; Karakucuk, A.; Azim, M.M.; Lokhat, D.; Rafatullah, M.; Ganash, M.; Kamal, M.A.; Ashraf, G.M. Essential Oils: Extraction Techniques, Pharmaceutical And Therapeutic Potential—A Review. Curr. Drug Metab. 2018, 19, 1100-1110. [CrossRef] [PubMed] 
59. Juliano, C.; Mattana, A.; Usai, M. Composition and in vitro antimicrobial activity of the essential oil of thymus herba-barona loisel growing wild in sardinia. J. Essent. Oil Res. 2000, 12, 516-522. [CrossRef]

60. Faleiro, M.L.; Miguel, M.G.; Ladeiro, F.; Venancio, F.; Tavares, R.; Brito, J.C.; Figueiredo, A.C.; Barroso, J.G.; Pedro, L.G. Antimicrobial activity of essential oils isolated from Portuguese endemic species of Thymus. Lett. Appl. Microbiol. 2003, 36, 35-40. [CrossRef]

61. Moghaddam, M.; Mehdizadeh, L. Chemistry of Essential Oils and Factors Influencing Their Constituents. In Soft Chemistry and Food Fermentation; Academic Press: Cambridge, MA, USA, 2017; pp. 379-419. [CrossRef]

62. Kokkini, S.; Karousou, R.; Dardioti, A.; Krigas, N.; Lanaras, T. Autumn essential oils of Greek oregano. Phytochemistry 1997, 44, 883-886. [CrossRef]

63. Cosentino, S.; Tuberoso, C.I.G.; Pisano, B.; Satta, M.; Mascia, V.; Arzedi, E.; Palmas, F. In-vitro antimicrobial activity and chemical composition of Sardinian Thymus essential oils. Lett. Appl. Microbiol. 1999, 29, 130-135. [CrossRef]

64. Jerkovic, I.; Mastelic, J.; Milos, M. The impact of both the season of collection and drying on the volatile constituents of Origanum vulgare L. ssp. hirtum grown wild in Croatia. Int. J. Food Sci. Technol. 2001, 36, 649-654. [CrossRef]

65. Sarmoum, R.; Haid, S.; Biche, M.; Djazouli, Z.; Zebib, B.; Merah, O. Effect of Salinity and Water Stress on the Essential Oil Components of Rosemary (Rosmarinus officinalis L.). Agronomy 2019, 9, 214. [CrossRef]

66. Marino, M.; Bersani, C.; Comi, G. Antimicrobial activity of the essential oils of Thymus vulgaris L. measured using a bioimpedometric method. J. Food Prot. 1999, 62, 1017-1023. [CrossRef]

67. Lis-Balchin, M.; Deans, S.G.; Eaglesham, E. Relationship between bioactivity and chemical composition of commercial essential oils. Flavour Fragr. J. 1998, 13, 98-104. [CrossRef]

68. Marino, M.; Bersani, C.; Comi, G. Impedance measurements to study the antimicrobial activity of essential oils from Lamiaceae and Compositae. Int. J. Food Microbiol. 2001, 67, 187-195. [CrossRef]

69. Sellami, I.H.; Wannes, W.A.; Bettaieb, I.; Berrima, S.; Chahed, T.; Marzouk, B.; Limam, F. Qualitative and quantitative changes in the essential oil of Laurus nobilis L. leaves as affected by different drying methods. Food Chem. 2011, 126, 691-697. [CrossRef]

70. Nejad Ebrahimi, S.; Hadian, J.; Ranjbar, H. Essential oil compositions of different accessions of Coriandrum sativum L. from Iran. Nat. Prod. Res. 2010, 24, 1287-1294. [CrossRef]

71. Msaada, K.; Hosni, K.; Taarit, M.B.; Hammami, M.; Marzouk, B. Effects of growing region and maturity stages on oil yield and fatty acid composition of coriander (Coriandrum sativum L.) fruit. Sci. Hortic. 2009, 120, 525-531. [CrossRef]

72. Daferera, D.J.; Ziogas, B.N.; Polissiou, M.G. GC-MS analysis of essential oils from some Greek aromatic plants and their fungitoxicity on Penicillium digitatum. J. Agric. Food Chem. 2000, 48, 2576-2581. [CrossRef]

73. Daferera, D.J.; Ziogas, B.; Polissiou, M.G. The effectiveness of plant essential oils on the growth of Botrytis cinerea, Fusarium sp. and Clavibacter michiganensis subsp. michiganensis. Crop Prot. 2003, 39-44. [CrossRef]

74. Pintore, G.; Usai, M.; Bradesi, P.; Juliano, C.; Boatto, G.; Tomi, F.; Chessa, M.; Cerri, R.; Casanova, J. Chemical composition and antimicrobial activity of Rosmarinus officinalis L. oils from Sardinia and Corsica. Flavour Fragr. J. 2002, 17, 15-19. [CrossRef]

75. Lens-Lisbonne, C.; Cremieux, A.; Maillard, C.; Balansard, G. Methodes d'evaluation de l'activite' antibacterienne des huiles essentielles: Application aux essences de thym et de cannelle. J. De Pharm. De Belg. 1987, 42, 297-302.

76. Burits, M.; Bucar, F. Antioxidant activity of Nigella sativa essential oil. Phytother. Res. 2000, 14, 323-328. [CrossRef]

77. Dob, T.; Dahmane, D.; Chelghoum, C. Essential oil composition of Juniperus oxycedrus growing in Algeria. Pharm. Biol. 2006, 44, 1-6. [CrossRef]

78. Rana, V.S.; Juyal, J.P.; Blazquez, M.A. Chemical constituents of essential oil of Pelargonium graveolens leaves. Int. J. Aromather. 2002, 12, 216-218. [CrossRef]

79. Lawrence, B.M. The botanical and chemical aspects of oregano. Perfum. Flavorist 1984, 9, 41-51.

80. Prudent, D.; Perineau, F.; Bessiere, J.M.; Michel, G.M.; Baccou, J.C. Analysis of the essential oil of wild oregano from martinique (Coleus aromaticus Benth.) -Evaluation of its bacteriostatic and fungistatic properties. J. Essent. Oil Res. 1995, 7, 165-173. [CrossRef]

81. Charai, M.; Mosaddak, M.; Faid, M. Chemical Composition and Antimicrobial Activities of Two Aromatic Plants: Origanum majorana L. and O. compactum Benth. J. Essent. Oil Res. 1996, 8, 657-664. [CrossRef]

82. Sivropoulou, A.; Papanikolaou, E.; Nikolaou, C.; Kokkini, S.; Lanaras, T.; Arsenakis, M. Antimicrobial and cytotoxic activities of Origanum essential oils. J. Agric. Food Chem. 1996, 44, 1202-1205. [CrossRef]

83. Demetzos, C.; Perdetzoglou, D.K.; Tan, K. Composition and antimicrobial studies of the oils of Origanum calcaratum juss. and O. scabrum boiss. et Heldr. from Greece. J. Essent. Oil Res. 2001, 13, 460-462. [CrossRef]

84. Bourgou, S.; Tammar, S.; Salem, N.; Mkadmini, K.; Msaada, K. Phenolic Composition, Essential Oil, and Antioxidant Activity in the Aerial Part of Artemisia Herba-Alba from Several Provenances: A Comparative Study. Int. J. Food Prop. 2016, 19, 549-563. [CrossRef]

85. Hernandez, E. Essential Oils | Distillation. In Encyclopedia of Separation Science; Elsevier: Amsterdam, The Netherlands, 2000; pp. 2739-2744. [CrossRef]

86. Kalemba, D.A.A.K.; Kunicka, A. Antibacterial and Antifungal Properties of Essential Oils. Curr. Med. Chem. 2005, 10, 813-829. [CrossRef]

87. Tongnuanchan, P.; Benjakul, S. Essential Oils: Extraction, Bioactivities, and Their Uses for Food Preservation. J. Food Sci. 2014, 79, R1231-R1249. [CrossRef] 
88. Rojas-Graü, M.A.; Raybaudi-Massilia, R.M.; Soliva-Fortuny, R.C.; Avena-Bustillos, R.J.; McHugh, T.H.; Martín-Belloso, O. Apple puree-alginate edible coating as carrier of antimicrobial agents to prolong shelf-life of fresh-cut apples. Postharvest Biol. Technol. 2007, 45, 254-264. [CrossRef]

89. Salvia-Trujillo, L.; Rojas-Graü, M.A.; Soliva-Fortuny, R.; Martín-Belloso, O. Use of antimicrobial nanoemulsions as edible coatings: Impact on safety and quality attributes of fresh-cut fuji apples. Postharvest Biol. Technol. 2015, 105, 8-16. [CrossRef]

90. Donsì, F.; Annunziata, M.; Sessa, M.; Ferrari, G. Nanoencapsulation of essential oils to enhance their antimicrobial activity in foods. Lwt Food Sci. Technol. 2011, 44, 1908-1914. [CrossRef]

91. Taylor, L. The Healing Power of Rainforest Herbs: A Guide to Understanding and Using Herbal Medicinals; Square One Publishers: New York, NY, USA, 2005.

92. Selim, S. Antimicrobial activity of essential oils against vancomycin-resistant enterococci (vre) and Escherichia coli o157:h7 in feta soft cheese and minced beef meat. Braz. J. Microbiol. 2011, 42, 187-196. [CrossRef] [PubMed]

93. Dima, C.; Dima, S. Essential oils in foods: Extraction, stabilization, and toxicity. Curr. Opin. Food Sci. 2015, 5, 29-35. [CrossRef]

94. Worsfold, P.; Townshend, A.; Poole, C.F.; Miró, M. (Eds.) Encyclopedia of Analytical Science, 2nd ed.; Elsevier Inc: Amsterdam, The Netherlands; London, UK; New York, NY, USA, 2019; pp. 554-561. [CrossRef]

95. Turek, C.; Stintzing, F.C. Stability of essential oils: A review. Compr. Rev. Food Sci. Food Saf. 2013, 12, 40-53. [CrossRef]

96. Özbek, Z.A.; Ergönül, P.G. A Review on Encapsulation of Oils. Celal Bayar Üniversitesi Fen Bilimleri Dergisi 2017, 13, 293-309. [CrossRef]

97. Sagiri, S.S.; Anis, A.; Pal, K. Review on Encapsulation of Vegetable Oils: Strategies, Preparation Methods, and Applications. Polym. Plast. Technol. Eng. 2016, 55, 291-311. [CrossRef]

98. Maes, C.; Bouquillon, S.; Fauconnier, M.L. Encapsulation of Essential Oils for the Development of Biosourced Pesticides with Controlled Release: A Review. Molecules 2019, 24, 2539. [CrossRef]

99. Nehme, R.; Blel, W.; Montillet, A.; Bellettre, J.; Marchal, L. Production of oil in water emulsions in microchannels at high throughput: Evaluation of emulsions in view of cosmetic, nutraceutical or pharmaceutical applications. Chem. Eng. Process. Process Intensif. 2021, 161, 108301. [CrossRef]

100. Bakry, A.M.; Abbas, S.; Ali, B.; Majeed, H.; Abouelwafa, M.Y.; Mousa, A.; Liang, L. Microencapsulation of Oils: A Comprehensive Review of Benefits, Techniques, and Applications. Compr. Rev. Food Sci. Food Saf. 2016, 15, 143-182. [CrossRef]

101. Almeida, F.N.; Htoo, J.K.; Thomson, J.; Stein, H.H. Amino acid digestibility in camelina products fed to growing pigs. Can. J. Anim. Sci. 2013, 93, 335-343. [CrossRef]

102. Ghalem, B.R.; Zouaoui, B. Microbiological, physico-chemical and sensory quality aspects of yoghurt enriched with Rosmarinus officinalis oil. Afr. J. Biotechnol. 2013, 12, 192-198. [CrossRef]

103. Shah, B.; Davidson, P.M.; Zhong, Q. Encapsulation of eugenol using Maillard-type conjugates to form transparent and heat stable nanoscale dispersions. Lwt Food Sci. Technol. 2012, 49, 139-148. [CrossRef]

104. Benjemaa, M.; Neves, M.A.; Falleh, H.; Isoda, H.; Ksouri, R.; Nakajima, M. Nanoencapsulation of Thymus capitatus essential oil: Formulation process, physical stability characterization and antibacterial efficiency monitoring. Ind. Crop. Prod. 2018, 113, 414-421. [CrossRef]

105. Timilsena, Y.P.; Akanbi, T.O.; Khalid, N.; Adhikari, B.; Barrow, C.J. Complex coacervation: Principles, mechanisms and applications in microencapsulation. Int. J. Biol. Macromol. 2019, 121, 1276-1286. [CrossRef]

106. Chapeau, A.L.; Bertrand, N.; Briard-Bion, V.; Hamon, P.; Poncelet, D.; Bouhallab, S. Coacervates of whey proteins to protect and improve the oral delivery of a bioactive molecule. J. Funct. Foods 2017, 38, 197-204. [CrossRef]

107. Hajjali, H. Assemblage Nanoparticules Lipidiques Solides-Polysaccharide: Étude des Propriétés Physico-Chimiques Pour la Vectorisation d'un Polyphénol. Université de Lorraine, France 2015. Available online: http://www.culture.gouv.fr/culture/ infos-pratiques / droits / protection.htm (accessed on 4 January 2021).

108. Torchilin, V.P. Targeted pharmaceutical nanocarriers for cancer therapy and imaging. AAPS J. 2007, 9, E128-E147. [CrossRef]

109. Kulkarni, M.; Greiser, U.; O’Brien, T.; Pandit, A. Liposomal gene delivery mediated by tissue-engineered scaffolds. Trends Biotechnol. 2010, 28, 28-36. [CrossRef] [PubMed]

110. Setya, S.; Talegaonkar, S. Nanoemulsions:formulation methods and stability aspects. World J. Pharm. Pharm. Sci. 2014, 3, 2214-2228.

111. Liu, C.H.; Yu, S.Y. Cationic nanoemulsions as non-viral vectors for plasmid DNA delivery. Colloids Surf. B Biointerfaces 2010, 79, 509-515. [CrossRef]

112. Qian, C.; McClements, D.J. Formation of nanoemulsions stabilized by model food-grade emulsifiers using high-pressure homogenization: Factors affecting particle size. Food Hydrocoll. 2011, 25, 1000-1008. [CrossRef]

113. Delmas, T.; Piraux, H.; Couffin, A.C.; Texier, I.; Vinet, F.; Poulin, P.; Cates, M.E.; Bibette, J. How to prepare and stabilize very small nanoemulsions. Langmuir 2011, 27, 1683-1692. [CrossRef]

114. Alhaj, N.A.; Shamsudin, M.N.; Alipiah, N.M.; Zamri, H.F.; Bustamam, A.; Ibrahim, S.; Abdullah, R. Characterization of Nigella sativa L. essential oil-loaded solid lipid nanoparticles. Am. J. Pharmacol. Toxicol. 2010, 5, 52-57. [CrossRef]

115. Bouyahya, A.; Bakri, Y.; Et-Touys, A.; Talbaoui, A.; Khouchlaa, A.; Charfi, S.; Abrini, J.; Dakka, N. Résistance aux antibiotiques et mécanismes d'action des huiles essentielles contre les bactériesResistance to antibiotics and mechanisms of action of essential oils against bacteria. Phytothérapie 2017. [CrossRef] 
116. Scotti, R.; Stringaro, A.; Nicolini, L.; Zanellato, M.; Boccia, P.; Maggi, F.; Gabbianelli, R. Effects of Essential Oils from Cymbopogon spp. and Cinnamomum verum on Biofilm and Virulence Properties of Escherichia coli O157:H7. Antibiotics 2021, 10, 113. [CrossRef]

117. Assane, I.M.; Valladão, G.M.R.; Pilarski, F. Chemical composition, cytotoxicity and antimicrobial activity of selected plant-derived essential oils against fish pathogens. Aquac. Res. 2021, 52, 793-809. [CrossRef]

118. Iseppi, R.; Tardugno, R.; Brighenti, V.; Benvenuti, S.; Sabia, C.; Pellati, F.; Messi, P. Phytochemical Composition and In Vitro Antimicrobial Activity of Essential Oils from the Lamiaceae Family against Streptococcus agalactiae and Candida albicans Biofilms. Antibiotics 2020, 9, 592. [CrossRef]

119. Nafis, A.; Kasrati, A.; Jamali, C.A.; Custódio, L.; Vitalini, S.; Iriti, M.; Hassani, L. A Comparative Study of the in Vitro Antimicrobial and Synergistic Effect of Essential Oils from Laurus nobilis L. and Prunus armeniaca L. from Morocco with Antimicrobial Drugs: New Approach for Health Promoting Products. Antibiotics 2020, 9, 140. [CrossRef]

120. Iseppi, R.; Di Cerbo, A.; Aloisi, P.; Manelli, M.; Pellesi, V.; Provenzano, C.; Camellini, S.; Messi, P.; Sabia, C. In Vitro Activity of Essential Oils Against Planktonic and Biofilm Cells of Extended-Spectrum $\beta$-Lactamase (ESBL)/Carbapenamase-Producing Gram-Negative Bacteria Involved in Human Nosocomial Infections. Antibiotics 2020, 2020, 272. [CrossRef]

121. Somrani, M.; Inglés, M.C.; Debbabi, H.; Abidi, F.; Palop, A. Garlic, onion, and cinnamon essential oil anti-biofilms' effect against listeria monocytogenes. Foods 2020, 9, 567. [CrossRef]

122. Miguel, M.G. Antioxidant and anti-inflammatory activities of essential oils: A short review. Molecules 2010, 15, 9252-9287. [CrossRef]

123. Sandner, G.; Heckmann, M.; Weghuber, J. Immunomodulatory activities of selected essential oils. Biomolecules 2020, 10, 1139. [CrossRef]

124. Chandrakanthan, M.; Handunnetti, S.M.; Sirimal, G.; Premakumara, A.; Kathirgamanathar, S. Topical Anti-Inflammatory Activity of Essential Oils of Alpinia calcarata Rosc., Its Main Constituents, and Possible Mechanism of Action. Evid. Based Complementary Altern. Med. 2020, 2020. [CrossRef]

125. Kim, T.; Song, B.; Sang Cho, K.; Lee, I.-S. Therapeutic Potential of Volatile Terpenes and Terpenoids from Forests for Inflammatory Diseases. Int. J. Mol. Sci. 2020, 21, 2187. [CrossRef]

126. Inouye, S.; Abe, S. Nouvelle approache de l'aromathérapie anti-infectieuse. Phytotherapie 2007, 5, 2-4. [CrossRef]

127. Chouhan, S.; Guleria, S. Anti-inflammatory Activity of Medicinal Plants: Present Status and Future Perspectives. In Botanical Leads for Drug Discovery; Springer: Singapore, 2020; pp. 67-92. [CrossRef]

128. Giovannini, D.; Gismondi, A.; Basso, A.; Canuti, L.; Braglia, R.; Canini, A.; Mariani, F.; Cappelli, G. Lavandula angustifolia mill. Essential oil exerts antibacterial and anti-inflammatory effect in macrophage mediated immune response to staphylococcus aureus. Immunol. Investig. 2016, 45, 11-28. [CrossRef]

129. Benchaar, C.; Greathead, H. Essential oils and opportunities to mitigate enteric methane emissions from ruminants. Anim. Feed Sci. Technol. 2011, 166-167, 338-355. [CrossRef]

130. Manzanilla, E.G.; Nofrarias, M.; Anguita, M.; Castillo, M.; Perez, J.F.; Martin-Orue, S.M.; Kamel, C.; Gasa, J. Effects of butyrate, avilamycin, and a plant extract combination on the intestinal equilibrium of early-weaned pigs. J. Anim. Sci. 2006, 84, 2743-2751. [CrossRef]

131. Li, P.; Piao, X.; Ru, Y.; Han, X.; Xue, L.; Zhang, H. Effects of adding essential oil to the diet of weaned pigs on performance, nutrient utilization, immune response and intestinal health. Asian-Australas. J. Anim. Sci. 2012, 25, 1617-1626. [CrossRef] [PubMed]

132. Su, G.; Zhou, X.; Wang, Y.; Chen, D.; Chen, G.; Li, Y.; He, J. Effects of plant essential oil supplementation on growth performance, immune function and antioxidant activities in weaned pigs. Lipids Health Dis. 2018, 17, 139. [CrossRef] [PubMed]

133. Xu, Y.; Lahaye, L.; He, Z.; Zhang, J.; Yang, C.; Piao, X. Micro-encapsulated essential oils and organic acids combination improves intestinal barrier function, inflammatory responses and microbiota of weaned piglets challenged with enterotoxigenic Escherichia coli F4 (K88+). Anim. Nutr. 2020, 6, 269-277. [CrossRef] [PubMed]

134. Zou, Y.; Xiang, Q.; Wang, J.; Peng, J.; Wei, H. Oregano Essential Oil Improves Intestinal Morphology and Expression of Tight Junction Proteins Associated with Modulation of Selected Intestinal Bacteria and Immune Status in a Pig Model. BioMed Res. Int. 2016, 2016. [CrossRef] [PubMed]

135. Xie, Z.; Zhao, Q.; Wang, H.; Wen, L.; Li, W.; Zhang, X.; Lin, W.; Li, H.; Xie, Q.; Wang, Y. Effects of antibacterial peptide combinations on growth performance, intestinal health, and immune function of broiler chickens. Poult. Sci. 2020, 99, 6481-6492. [CrossRef]

136. Liu, S.D.; Song, M.H.; Yun, W.; Lee, J.H.; Kim, H.B.; Cho, J.H. Effect of carvacrol essential oils on immune response and inflammation-related genes expression in broilers challenged by lipopolysaccharide. Poult. Sci. 2019, 98, 2026-2033. [CrossRef]

137. Montironi, I.D.; Reinoso, E.B.; Paullier, V.C.; Siri, M.I.; Pianzzola, M.J.; Moliva, M.; Campra, N.; Bagnis, G.; LaRocque-de-Freitas, I.F.; Decote-Ricardo, D.; et al. Minthostachys verticillata essential oil activates macrophage phagocytosis and modulates the innate immune response in a murine model of Enterococcus faecium mastitis. Res. Vet. Sci. 2019, 125, 333-344. [CrossRef] [PubMed]

138. De Nardi, R.; Marchesini, G.; Plaizier, J.C.; Li, S.; Khafipour, E.; Ricci, R.; Andrighetto, I.; Segato, S. Use of dicarboxylic acids and polyphenols to attenuate reticular $\mathrm{pH}$ drop and acute phase response in dairy heifers fed a high grain diet. BMC Vet. Res. 2014, 10. [CrossRef]

139. Ceciliani, F.; Ceron, J.J.; Eckersall, P.D.; Sauerwein, H. Acute phase proteins in ruminants. J. Proteom. 2012, 75, 4207-4231. [CrossRef] [PubMed] 
140. Keane, O.M. Symposium review: Intramammary infections-Major pathogens and strain-associated complexity. J. Dairy Sci. 2019, 102, 4713-4726. [CrossRef]

141. Halasa, T.; Huijps, K.; Østerås, O.; Hogeveen, H. Economic effects of bovine mastitis and mastitis management: A review. Vet. Q. 2007, 29, 18-31. [CrossRef] [PubMed]

142. Lopes, T.S.; Fontoura, P.S.; Oliveira, A.; Rizzo, F.A.; Silveira, S.; Streck, A.F. Use of plant extracts and essential oils in the control of bovine mastitis. Res. Vet. Sci. 2020. [CrossRef]

143. Hogeveen, H.; Van Der Voort, M. Assessing the economic impact of an endemic disease: The case of mastitis. Oie Rev. Sci. Tech. 2017, 36, 217-226. [CrossRef] [PubMed]

144. Halasa, T.; Nielen, M.; De Roos, A.P.W.; Van Hoorne, R.; de Jong, G.; Lam, T.J.G.M.; Van Werven, T.; Hogeveen, H. Production loss due to new subclinical mastitis in Dutch dairy cows estimated with a test-day model. J. Dairy Sci. 2009, 92, 599-606. [CrossRef] [PubMed]

145. Andersson, D.I.; Hughes, D. Persistence of antibiotic resistance in bacterial populations. FEMS Microbiol. Rev. 2011, 35, 901-911. [CrossRef] [PubMed]

146. Sharma, C.; Rokana, N.; Chandra, M.; Singh, B.P.; Gulhane, R.D.; Gill, J.P.S.; Ray, P.; Puniya, A.K.; Panwar, H. Antimicrobial resistance: Its surveillance, impact, and alternative management strategies in dairy animals. Front. Vet. Sci. 2018, 4, 237. [CrossRef] [PubMed]

147. Burt, S. Essential oils: Their antibacterial properties and potential applications in foods-A review. Int. J. Food Microbiol. 2004, 94, 223-253. [CrossRef]

148. Aiemsaard, J.; Aiumlamai, S.; Aromdee, C.; Taweechaisupapong, S.; Khunkitti, W. The effect of lemongrass oil and its major components on clinical isolate mastitis pathogens and their mechanisms of action on Staphylococcus aureus DMST 4745. Res. Vet. Sci. 2011, 91. [CrossRef] [PubMed]

149. Tavares, T.D.; Antunes, J.C.; Padrão, J.; Ribeiro, A.I.; Zille, A.; Amorim, M.T.P.; Felgueiras, H.P. Activity of Specialized Biomolecules against Gram-Positive and Gram-Negative Bacteria. Antibiotics 2020, 9, 314. [CrossRef] [PubMed]

150. Kher, M.N.; Sheth, N.R.; Bhatt, V.D. In Vitro Antibacterial Evaluation of Terminalia chebula as an Alternative of Antibiotics against Bovine Subclinical Mastitis. Anim. Biotechnol. 2019, 30, 151-158. [CrossRef] [PubMed]

151. Fox, L.K.; Zadoks, R.N.; Gaskins, C.T. Biofilm production by Staphylococcus aureus associated with intramammary infection. Vet. Microbiol. 2005, 107, 295-299. [CrossRef] [PubMed]

152. Abboud, M.; El Rammouz, R.; Jammal, B.; Sleiman, M. In vitro and in vivo antimicrobial activity of two essential oils Thymus vulgaris and Lavandula angustifolia against bovine Staphylococcus and Streptococcus mastitis pathogen. Middle East J. Agric. Res. 2015, 4, 975-983.

153. Cho, B.W.; Cha, C.N.; Lee, S.M.; Kim, M.J.; Park, J.Y.; Yoo, C.Y.; Son, S.E.; Kim, S.; Lee, H.J. Therapeutic effect of oregano essential oil on subclinical bovine mastitis caused by Staphylococcus aureus and Escherichia coli. Korean J. Vet. Res. 2015, 55, $253-257$. [CrossRef]

154. Kammerer, M.; Le Guenic, M.; Roussel, P.; Linclau, O.; Cartaud, G.; Tainturier, D.; Larrat, M.; Bareille, N. Le traitement des mammites cliniques de la vache laitière par des huiles essentielles. Innov. Agron. 2009, 4, 79-83.

155. Corre, C. L'utilisation de L'aromathérapie Dans les Élevages Français: État des Lieux, Efficacité et Limites. Available online: https: / / hal.inrae.fr/hal-02788515/document (accessed on 1 February 2021).

156. Amorati, R.; Foti, M.C.; Valgimigli, L. Antioxidant Activity of Essential Oils. J. Agric. Food Chem. 2018, 61. [CrossRef] [PubMed]

157. Castillo, C.; Hernandez, J.; Pereira, V.; Benedito, J.L. Update about Nutritional Strategies in Feedlot for Preventing Ruminal Acidosis. Adv. Zool. Res. 2012, 4, 1-84.

158. Younsi, F.; Mehdi, S.; Aissi, O.; Rahali, N.; Jaouadi, R.; Boussaid, M.; Roura, E. Review on in vivo and in vitro methods evaluation of antioxidant activity. Flavour Fragr. J. 2020, 25, 282. [CrossRef]

159. Amaral, A.B.; SILVA, M.V.D.; LANNES, S.C.D.S. Lipid oxidation in meat: Mechanisms and protective factors a review. Food Sci. Technol. 2018, 38, 1-15. [CrossRef]

160. Elshafie, H.S.; Camele, I. An Overview of the Biological Effects of Some Mediterranean Essential Oils on Human Health. BioMed Res. Int. 2017, 2017, 9268468. [CrossRef] [PubMed]

161. Sharma, S.; Barkauskaite, S.; Jaiswal, A.K.; Jaiswal, S. Essential oils as additives in active food packaging. Food Chem. 2021, 343, 128403. [CrossRef] [PubMed]

162. Mimica-Dukić, N.; Orčić, D.; Lesjak, M.; Šibul, F. Essential oils as powerful antioxidants: Misconception or scientific fact. In ACS Symposium Series; American Chemical Society: Washington, DC, USA, 2016; Volume 1218, pp. 187-208. [CrossRef]

163. Alam, M.N.; Bristi, N.J.; Rafiquzzaman, M. Review on in vivo and in vitro methods evaluation of antioxidant activity. Saudi Pharm. J. 2013, 21, 143-152. [CrossRef]

164. Jugreet, B.S.; Suroowan, S.; Rengasamy, R.R.K.; Mahomoodally, M.F. Chemistry, bioactivities, mode of action and industrial applications of essential oils. Trends Food Sci. Technol. 2020, 101, 89-105. [CrossRef]

165. Zhai, H.; Liu, H.; Wang, S.; Wu, J.; Kluenter, A.M. Potential of essential oils for poultry and pigs. Anim. Nutr. 2018, 4, 179-186. [CrossRef] [PubMed]

166. Bouhaddouda, N.; Aouadi, S.; Labiod, R. Evaluation of chemical composition and biological activities of essential oil and methanolic extract of Origanum vulgare L. ssp. glandulosum (DESF.) Ietswaart from Algeria. Int. J. Pharmacogn. Phytochem. Res. 2016, 8, 104-112. 
167. Viuda-Martos, M.; Ruiz Navajas, Y.; Sánchez Zapata, E.; Fernández-López, J.; Pérez-Álvarez, J.A. Antioxidant activity of essential oils of five spice plants widely used in a Mediterranean diet. Flavour Fragr. J. 2010, 25, 13-19. [CrossRef]

168. Bounatirou, S.; Smiti, S.; Miguel, M.G.; Faleiro, L.; Rejeb, M.N.; Neffati, M.; Costa, M.M.; Figueiredo, A.C.; Barroso, J.G.; Pedro, L.G. Chemical composition, antioxidant and antibacterial activities of the essential oils isolated from Tunisian Thymus capitatus Hoff. et Link. Food Chem. 2007, 105, 146-155. [CrossRef]

169. Kulisic, T.; Radonic, A.; Katalinic, V.; Milos, M. Use of different methods for testing antioxidative activity of oregano essential oil. Food Chem. 2004, 85, 633-640. [CrossRef]

170. Franz, C.; Baser, K.; Windisch, W. Essential oils and aromatic plants in animal feeding a European perspective. A review. Flavour Fragr. J. 2010, 25, 327-340. [CrossRef]

171. Botsoglou, N.A.; Yannakopoulos, A.L.; Fletouris, D.J.; Tserveni-Goussi, A.S.; Fortomaris, P.D. Effect of Dietary Thyme on the Oxidative Stability of Egg Yolk. J. Agric. Food Chem. 1997, 45, 3711-3716. [CrossRef]

172. Youdim, K.A.; Deans, S.G. Effect of thyme oil and thymol dietary supplementation on the antioxidant status and fatty acid composition of the ageing rat brain. Br. J. Nutr. 2000, 83, 87-93. [CrossRef] [PubMed]

173. Estévez, M.; Cava, R. Effectiveness of rosemary essential oil as an inhibitor of lipid and protein oxidation: Contradictory effects in different types of frankfurters. Meat Sci. 2006, 72, 348-355. [CrossRef]

174. Takayama, C.; de-Faria, F.M.; de Almeida, A.C.A.; Dunder, R.J.; Manzo, L.P.; Socca, E.A.R.; Luiz-Ferreira, A. Chemical composition of Rosmarinus officinalis essential oil and antioxidant action against gastric damage induced by absolute ethanol in the rat. Asian Pac. J. Trop. Biomed. 2016, 6, 677-681. [CrossRef]

175. Kazemi, M. Phytochemical Composition, Antioxidant, Anti-inflammatory and Antimicrobial Activity of Nigella sativa L. Essential Oil. J. Essent. Oil Bear. Plants 2014, 17, 1002-1011. [CrossRef]

176. Bourgou, S.; Pichette, A.; Marzouk, B.; Legault, J. Bioactivities of black cumin essential oil and its main terpenes from Tunisia. S. Afr. J. Bot. 2010, 76, 210-216. [CrossRef]

177. Sultan, M.T.; Butt, M.S.; Karim, R.; Ahmad, N.; Ahmad, R.S.; Ahmad, W. Nigella sativa fixed and essential oil improves antioxidant status through modulation of antioxidant enzymes and immunity. Pak. J. Pharm. Sci. 2015, 28, 589-595. [PubMed]

178. El Jery, A.; Hasan, M.; Rashid, M.M.; Al Mesfer, M.K.; Danish, M.; Ben Rebah, F. Phytochemical characterization, and antioxidant and antimicrobial activities of essential oil from leaves of the common sage Salvia officinalis L. from Abha, Saudi Arabia. Asian Biomed. 2020, 14, 261-270. [CrossRef]

179. Ed-Dra, A.; Filali, F.R.; Presti, V.L.; Zekkori, B.; Nalbone, L.; Bouymajane, A.; Trabelsi, N.; Lamberta, F.; Bentayeb, A.; Giuffrida, A.; et al. Chemical composition, antioxidant capacity and antibacterial action of five Moroccan essential oils against Listeria monocytogenes and different serotypes of Salmonella enterica. Microb. Pathog. 2020, 149, 104510. [CrossRef]

180. Viuda-Martos, M.; Ruíz-Navajas, Y.; Fernández-López, J.; Pérez-Álvarez, J.A. Chemical Composition of the Essential Oils Obtained From Some Spices Widely Used in Mediterranean Region. Acta Chim. Slov. 2007, 54, 921-926.

181. Ben Khedher, M.R.; Ben Khedher, S.; Chaieb, I.; Tounsi, S.; Hammami, M. Chemical composition and biological activities of Salvia officinalis essential oil from Tunisia. Excli J. 2017, 16, 160-173. [CrossRef]

182. Mssillou, I.; Agour, A.; El Ghouizi, A.; Hamamouch, N.; Lyoussi, B.; Derwich, E. Chemical Composition, Antioxidant Activity, and Antifungal Effects of Essential Oil from Laurus nobilis L. Flowers Growing in Morocco. J. Food Qual. 2020, $2020,8819311$. [CrossRef]

183. Yilmaz, E.S.; Timur, M.; Aslim, B. Antimicrobial, Antioxidant Activity of the Essential Oil of Bay Laurel from Hatay, Turkey. J. Essent. Oil Bear. Plants 2013, 16, 108-116. [CrossRef]

184. Saab, A.M.; Tundis, R.; Loizzo, M.R.; Lampronti, I.; Borgatti, M.; Gambari, R.; Menichini, F.; Esseily, F.; Menichini, F. Antioxidant and antiproliferative activity of Laurus nobilis L. (Lauraceae) leaves and seeds essential oils against K562 human chronic myelogenous leukaemia cells. Nat. Prod. Res. 2012, 26, 1741-1745. [CrossRef]

185. Kačániová, M.; Galovičová, L.; Ivanišová, E.; Vukovic, N.L.; Štefániková, J.; Valková, V.; Borotová, P.; Žiarovská, J.; Terentjeva, M.; Felšöciová, S.; et al. Antioxidant, Antimicrobial and Antibiofilm Activity of Coriander (Coriandrum sativum L.) Essential Oil for Its Application in Foods. Foods 2020, 9, 282. [CrossRef]

186. Bozin, B.; Mimica-Dukic, N.; Samojlik, I.; Jovin, E. Antimicrobial and antioxidant properties of rosemary and sage (Rosmarinus officinalis L. and Salvia officinalis L., Lamiaceae) essential oils. J. Agric. Food Chem. 2007, 55, 7879-7885. [CrossRef] [PubMed]

187. Rašković, A.; Milanović, I.; Pavlović, N.; Ćebović, T.; Vukmirović, S.; Mikov, M. Antioxidant activity of rosemary (Rosmarinus officinalis L.) essential oil and its hepatoprotective potential. BMC Complement. Altern. Med. 2014, 14, 225. [CrossRef]

188. Ouariachi, E.; Paolini, J.; Bouyanzer, A.; Tomi, P.; Hammouti, B.; Salghi, R.; Costa, J. Chemical composition and antioxidant activity of essential oils and solvent extracts of Thymus capitatus (L.) Hoffmanns and link from Morocco. J. Med. Plant Res. 2011, 5, 5773-5778.

189. Goudjil, M.B.; Zighmi, S.; Hamada, D.; Mahcene, Z.; Bencheikh, S.E.; Ladjel, S. Biological activities of essential oils extracted from Thymus capitatus (Lamiaceae). S. Afr. J. Bot. 2020, 128, 274-282. [CrossRef]

190. Riahi, L.; Chograni, H.; Ziadi, S.; Zaouali, Y.; Zoghlami, N.; Mliki, A. Chemical profiles and antioxidant activities of the essential oils of two medicinal plant species grown in Tunisia. J. Essent. Oil Res. 2013, 25, 324-329. [CrossRef]

191. Sahin Yaglioglu, A.; Eser, F.; Yaglioglu, M.S.; Demirtas, I. The antiproliferative and antioxidant activities of the essential oils of Juniperus species from Turkey. Flavour Fragr. J. 2020, 35, 511-523. [CrossRef] 
192. Cheraif, K.; Bakchiche, B.; Gherib, A.; Bardaweel, S.K.; Çol Ayvaz, M.; Flamini, G.; Ascrizzi, R.; Ghareeb, M.A. Chemical Composition, Antioxidant, Anti-Tyrosinase, Anti-Cholinesterase and Cytotoxic Activities of Essential Oils of Six Algerian Plants. Molecules 2020, 25, 1710. [CrossRef]

193. Lohani, A.; Mishra, A.K.; Verma, A. Cosmeceutical potential of geranium and calendula essential oil: Determination of antioxidant activity and in vitro sun protection factor. J. Cosmet. Dermatol. 2019, 18, 550-557. [CrossRef] [PubMed]

194. Elansary, H.O.; Abdelgaleil, S.A.M.; Mahmoud, E.A.; Yessoufou, K.; Elhindi, K.; El-Hendawy, S. Effective antioxidant, antimicrobial and anticancer activities of essential oils of horticultural aromatic crops in northern Egypt. BMC Complement. Altern. Med. 2018, 18, 214. [CrossRef] [PubMed]

195. Simirgiotis, M.J.; Burton, D.; Parra, F.; López, J.; Muñoz, P.; Escobar, H.; Parra, C. Antioxidant and Antibacterial Capacities of Origanum vulgare L. Essential Oil from the Arid Andean Region of Chile and its Chemical Characterization by GC-MS. Metabolites 2020, 10, 414. [CrossRef]

196. Lairini, S.; Farah, A.; Taghzouti, K.; Lalami, A.E.O. Antioxidant and Antibacterial Activities of Artemisia herba-alba Asso Essential Oil from Middle Atlas, Morocco. Phytotherapie 2018, 16, S48-S54. [CrossRef]

197. Younsi, F.; Mehdi, S.; Aissi, O.; Rahali, N.; Jaouadi, R.; Boussaid, M.; Messaoud, C. Essential Oil Variability in Natural Populations of Artemisia campestris (L.) and Artemisia herba-alba (Asso) and Incidence on Antiacetylcholinesterase and Antioxidant Activities. Chem. Biodivers. 2017, 14, e1700017. [CrossRef]

198. Miguel, G.; Cruz, C.; Faleiro, M.L.; Simões, M.T.F.; Figueiredo, A.C.; Barroso, J.G.; Pedro, L.G. Salvia officinalis L. essential oils: Effect of hydrodistillation time on the chemical composition, antioxidant and antimicrobial activities. Nat. Prod. Res. 2011, 25, 526-541. [CrossRef]

199. Noirot, V.; Moncouldon, R.; Sauvant, D.; Bayourthe, C. Effet d'une Supplémentation en Huiles Essentielles et Composés D’huiles Essentielles Chez le Ruminant: Analyse Statistique. Rev. Med. Vet. 2007, 158, 587-597. Available online: https:/ /www.researchgate.net/publication/281798515_Effet_d $\backslash \mathrm{T} 1 \backslash$ textquoterightune_supplementation_en_huiles_essentielles_ et_composes_d $\backslash \mathrm{T} 1 \backslash$ textquoterighthuiles_essentielles_chez_le_ruminant_analyse_statistique (accessed on 1 February 2021).

200. Arzola-Alvarez, C.; Hume, M.E.; Anderson, R.C.; Latham, E.A.; Ruiz-Barrera, O.; Castillo-Castillo, Y.; Olivas-Palacios, A.L.; Felix-Portillo, M.; Armendariz-Rivas, R.L.; Arzola-Rubio, A.; et al. Influence of sodium chlorate, ferulic acid, and essential oils on Escherichia coli and porcine fecal microbiota. J. Anim. Sci. 2020, 98, 1-9. [CrossRef]

201. Yang, C.; Zhang, L.; Cao, G.; Feng, J.; Yue, M.; Xu, Y.; Dai, B.; Han, Q.; Guo, X. Effects of dietary supplementation with essential oils and organic acids on the growth performance, immune system, fecal volatile fatty acids, and microflora community in weaned piglets. J. Anim. Sci. 2019, 97, 133-143. [CrossRef] [PubMed]

202. Wei, H.K.; Xue, H.X.; Zhou, Z.X.; Peng, J. A carvacrol-thymol blend decreased intestinal oxidative stress and influenced selected microbes without changing the messenger RNA levels of tight junction proteins in jejunal mucosa of weaning piglets. Animal 2017, 11, 193-201. [CrossRef]

203. Singh, G.; Marimuthu, P.; de Heluani, C.S.; Catalan, C. Chemical constituents and antimicrobial and antioxidant potentials of essential oil and acetone extract of Nigella sativa seeds. J. Sci. Food Agric. 2005, 85, 2297-2306. [CrossRef]

204. Yang, C.; Kennes, Y.M.; Lepp, D.; Yin, X.; Wang, Q.; Yu, H.; Yang, C.; Gong, J.; Diarra, M.S. Effects of encapsulated cinnamaldehyde and citral on the performance and cecal microbiota of broilers vaccinated or not vaccinated against coccidiosis. Poult. Sci. 2020, 99, 936-948. [CrossRef] [PubMed]

205. Oh, S.Y.; Yun, W.; Lee, J.H.; Lee, C.H.; Kwak, W.K.; Cho, J.H. Effects of essential oil (blended and single essential oils) on anti-biofilm formation of Salmonella and Escherichia coli. J. Anim. Sci. Technol. 2017, 59. [CrossRef] [PubMed]

206. Patra, A.K. Effects of Essential Oils on Rumen Fermentation, Microbial Ecology and Ruminant Production. Asian J. Anim. Vet. Adv. 2011, 6, 416-428. [CrossRef]

207. Patra, A.K.; Yu, Z. Essential oils affect populations of some rumen bacteria in vitro as revealed by microarray (RumenBactArray) analysis. Front. Microbiol. 2015, 6. [CrossRef]

208. Oh, J.; Hristov, A.N. Effects of plant-derived bio-active compounds on rumen fermentation, nutrient utilization, immune response, and productivity of ruminant animals. In ACS Symposium Series; American Chemical Society: Washington, DC, USA, 2016; Volume 1218, pp. 167-186. [CrossRef]

209. Kim, H.; Jung, E.; Lee, H.G.; Kim, B.; Cho, S.; Lee, S.; Kwon, I.; Seo, J. Essential oil mixture on rumen fermentation and microbial community-An in vitro study. Asian-Australas. J. Anim. Sci. 2019, 32, 808-814. [CrossRef]

210. Alagawany, M.; Farag, M.R.; Abdelnour, S.A.; Elnesr, S.S. A review on the beneficial effect of thymol on health and production of fish. Rev. Aquac. 2021, 13, 632-641. [CrossRef]

211. Jafari, S.; Ebrahimi, M.; Goh, Y.M.; Rajion, M.A.; Jahromi, M.F.; Al-Jumaili, W.S. Manipulation of rumen fermentation and methane gas production by plant secondary metabolites (saponin, tannin and essential oil)—A review of ten-year studies. Ann. Anim. Sci. 2019, 19, 3-29. [CrossRef]

212. Torres, R.N.S.; Moura, D.C.; Ghedini, C.P.; Ezequiel, J.M.B.; Almeida, M.T.C. Meta-analysis of the effects of essential oils on ruminal fermentation and performance of sheep. Small Rumin. Res. 2020, 189. [CrossRef]

213. Lei, Z.; Zhang, K.; Li, C.; Jiao, T.; Wu, J.; Wei, Y.; Tian, K.; Li, C.; Tang, D.; Davis, D.I.; et al. Ruminal metagenomic analyses of goat data reveals potential functional microbiota by supplementation with essential oil-cobalt complexes. BMC Microbiol. 2019, 19, 30. [CrossRef] 
214. Benchaar, C.; Petit, H.V.; Berthiaume, R.; Ouellet, D.R.; Chiquette, J.; Chouinardt, P.Y. Effects of essential oils on digestion, ruminai fermentation, rumen microbial populations, milk production, and milk composition in dairy cows fed alfalfa silage or corn silage. J. Dairy Sci. 2007, 90, 886-897. [CrossRef]

215. Khiaosa-ard, R.; Zebeli, Q. Meta-analysis of the effects of essential oils and their bioactive compounds on rumen fermentation characteristics and feed efficiency in ruminants1. J. Anim. Sci. 2013, 91, 1819-1830. [CrossRef] [PubMed]

216. Calsamiglia, S.; Busquet, M.; Cardozo, P.W.; Castillejos, L.; Ferret, A. Invited review: Essential oils as modifiers of rumen microbial fermentation. J. Dairy Sci. 2007, 90, 2580-2595. [CrossRef]

217. Ratika, K.; James Singh, R.K. Plant Derived Essential Oil in Ruminant Nutrition-A Review. Int. J. Curr. Microbiol. Appl. Sci. 2018, 7, 1747-1753. [CrossRef]

218. Noirot, V.; Moncoulon, R.; Sauvant, D.; Bayourthe, C. Effet d'une supplémentation en huiles essentielles et composés d’huiles essentielles chez le ruminant: Analyse statistique. Rev. De Médecine Vétérinaire 2007, 158, 589-597.

219. Vargas, J.E.; Andrés, S.; López-Ferreras, L.; Snelling, T.J.; Yáñez-Ruíz, D.R.; García-Estrada, C.; López, S. Dietary supplemental plant oils reduce methanogenesis from anaerobic microbial fermentation in the rumen. Sci. Rep. 2020, 10, 1-9. [CrossRef] [PubMed]

220. Günal, M.; Pinski, B.; AbuGhazaleh, A.A. Evaluating the effects of essential oils on methane production and fermentation under in vitro conditions. Ital. J. Anim. Sci. 2017, 16, 500-506. [CrossRef]

221. Smeti, S.; Hajji, H.; Mekki, I.; Mahouachi, M.; Atti, N. Effects of dose and administration form of rosemary essential oils on meat quality and fatty acid profile of lamb. Small Rumin. Res. 2018, 158, 62-68. [CrossRef]

222. Benchaar, C. Diet supplementation with thyme oil and its main component thymol failed to favorably alter rumen fermentation, improve nutrient utilization, or enhance milk production in dairy cows. J. Dairy Sci. 2021, 104, 324-336. [CrossRef]

223. Rivaroli, D.C.; Guerrero, A.; Valero, M.V.; Zawadzki, F.; Eiras, C.E.; del Mar Campo, M.; Sañudo, C.; Jorge, A.M.; do Prado, I.N. Effect of essential oils on meat and fat qualities of crossbred young bulls finished in feedlots. Meat Sci. 2016, 121, 278-284. [CrossRef]

224. De Oliveira Monteschio, J.; de Souza, K.A.; Vital, A.C.P.; Guerrero, A.; Valero, M.V.; Kempinski, E.M.B.C.; Barcelos, V.C.; Nascimento, K.F.; do Prado, I.N. Clove and rosemary essential oils and encapsuled active principles (eugenol, thymol and vanillin blend) on meat quality of feedlot-finished heifers. Meat Sci. 2017, 130, 50-57. [CrossRef]

225. Harris, S.E.; Huff-Lonergan, E.; Lonergan, S.M.; Jones, W.R.; Rankins, D. Antioxidant status affects color stability and tenderness of calcium chloride-injected beef. J. Anim. Sci. 2001, 79, 666-677. [CrossRef]

226. Garcia, L.G.S.; da Rocha, M.G.; Lima, L.R.; Cunha, A.P.; de Oliveira, J.S.; de Andrade, A.R.C.; Ricardo, N.M.P.S.; Pereira-Neto, W.A.; Sidrim, J.J.C.; Rocha, M.F.G.; et al. Essential oils encapsulated in chitosan microparticles against Candida albicans biofilms. Int. J. Biol. Macromol. 2021, 166, 621-632. [CrossRef] [PubMed]

227. Al-Suwaiegh, S.B.; Morshedy, S.A.; Mansour, A.T.; Ahmed, M.H.; Zahran, S.M.; Alnemr, T.M.; Sallam, S.M.A. Effect of an Essential Oil Blend on Dairy Cow Performance during Treatment and Post-Treatment Periods. Sustainability 2020, 12, 9123. [CrossRef]

228. El-Essawy, A.M.; Anele, U.Y.; Abdel-Wahed, A.M.; Abdou, A.R.; Khattab, I.M. Effects of anise, clove and thyme essential oils supplementation on rumen fermentation, blood metabolites, milk yield and milk composition in lactating goats. Anim. Feed Sci. Technol. 2021, 271, 114760. [CrossRef]

229. Soltan, Y.A.; Natel, A.S.; Araujo, R.C.; Morsy, A.S.; Abdalla, A.L. Progressive adaptation of sheep to a microencapsulated blend of essential oils: Ruminal fermentation, methane emission, nutrient digestibility, and microbial protein synthesis. Anim. Feed Sci. Technol. 2018, 237, 8-18. [CrossRef]

230. Morsy, T.A.; Kholif, S.M.; Matloup, O.H.; Abdo, M.M.; El-Shafie, M.H. Impact of Anise, Clove and Juniper Oils as Feed additives on the productive performance of lactating goats. Int. J. Dairy Sci. 2012, 7, 20-28. [CrossRef]

231. Kholif, A.E.; Kassab, A.Y.; Azzaz, H.H.; Matloup, O.H.; Hamdon, H.A.; Olafadehan, O.A.; Morsy, T.A. Essential oils blend with a newly developed enzyme cocktail works synergistically to enhance feed utilization and milk production of Farafra ewes in the subtropics. Small Rumin. Res. 2018, 161, 43-50. [CrossRef]

232. Göksen, G.; Fabra, M.J.; Pérez-Cataluña, A.; Ekiz, H.I.; Sanchez, G.; López-Rubio, A. Biodegradable active food packaging structures based on hybrid cross-linked electrospun polyvinyl alcohol fibers containing essential oils and their application in the preservation of chicken breast fillets. Food Packag. Shelf Life 2021, 27, 100613. [CrossRef]

233. Dong, Z.; Xu, F.; Ahmed, I.; Li, Z.; Lin, H. Characterization and preservation performance of active polyethylene films containing rosemary and cinnamon essential oils for Pacific white shrimp packaging. Food Control 2018, 92, 37-46. [CrossRef]

234. Buendía, L.; Soto, S.; Ros, M.; Antolinos, V.; Navarro, L.; Sánchez, M.J.; Martínez, G.B.; López, A. Innovative cardboard active packaging with a coating including encapsulated essential oils to extend cherry tomato shelf life. LWT 2019, 116, 108584. [CrossRef]

235. Alizadeh Behbahani, B.; Noshad, M.; Jooyandeh, H. Improving oxidative and microbial stability of beef using Shahri Balangu seed mucilage loaded with Cumin essential oil as a bioactive edible coating. Biocatal. Agric. Biotechnol. 2020, 24, 101563. [CrossRef]

236. Artiga-Artigas, M.; Acevedo-Fani, A.; Martín-Belloso, O. Improving the shelf life of low-fat cut cheese using nanoemulsion-based edible coatings containing oregano essential oil and mandarin fiber. Food Control 2017, 76, 1-12. [CrossRef]

237. Hashemi, S.M.B.; Khorram, S.B.; Sohrabi, M. Antioxidant Activity of Essential Oils in Foods. In Essential Oils in Food Processing: Chemistry, Safety and Applications; Wiley: Hoboken, NJ, USA, 2017; pp. 247-265. [CrossRef] 
238. Estévez, M.; Ventanas, S.; Cava, R. Protein oxidation in frankfurters with increasing levels of added rosemary essential oil: Effect on color and texture deterioration. J. Food Sci. 2005, 70, c427-c432. [CrossRef]

239. Bozkurt, H. Comparison of the effects of sesame and Thymbra spicata oil during the manufacturing of Turkish dry-fermented sausage. Food Control 2007, 18, 149-156. [CrossRef]

240. Martín-Sánchez, A.M.; Chaves-López, C.; Sendra, E.; Sayas, E.; Fenández-López, J.; Pérez-Álvarez, J.Á. Lipolysis, proteolysis and sensory characteristics of a Spanish fermented dry-cured meat product (salchichón) with oregano essential oil used as surface mold inhibitor. Meat Sci. 2011, 89, 35-44. [CrossRef]

241. Alsaiqali, M.; El-Shibiny, A.; El-Shibiny, A.; Adel, M.; Abdel-Samie, M.; Ghoneim, S. Use of Some Essential Oils as Antimicrobial Agents to Control Pathogenic Bacteria in Beef Burger. World J. Dairy Food Sci. 2016, 11, 109-120. [CrossRef]

242. Pateiro, M.; Barba, F.J.; Domínguez, R.; Sant'Ana, A.S.; Khaneghah, A.M.; Gavahian, M.; Gómez, B.; Lorenzo, J.M. Essential oils as natural additives to prevent oxidation reactions in meat and meat products: A review. Food Res. Int. 2018, 113, 156-166. [CrossRef] [PubMed]

243. Lee, R.F. Photo-oxidation and Photo-toxicity of Crude and Refined Oils. Spill Sci. Technol. Bull. 2003, 8, 157-162. [CrossRef]

244. Terenina, M.B.; Misharina, T.A.; Krikunova, N.I.; Alinkina, E.S.; Fatkulina, L.D.; Vorob'eva, A.K. Oregano essential oil as an inhibitor of higher fatty acid oxidation. Prikl. Biokhimiia I Mikrobiol. 2011, 47, 490-494. [CrossRef]

245. Özcan, M.M.; Arslan, D. Antioxidant effect of essential oils of rosemary, clove and cinnamon on hazelnut and poppy oils. Food Chem. 2011, 129, 171-174. [CrossRef]

246. Gavahian, M.; Hashemi, S.M.; Khaneghah, A.M.; Tehrani, M.A. Ohmically extracted Zenyan essential oils as natural antioxidant in mayonnaise. Int. Food Res. J. 2013, 20, 3189-3195.

247. Ben Jemaa, M.; Falleh, H.; Saada, M.; Oueslati, M.; Snoussi, M.; Ksouri, R. Thymus capitatus essential oil ameliorates pasteurization efficiency. J. Food Sci. Technol. 2018, 55, 3446-3452. [CrossRef] [PubMed]

248. Elama, C.; Alayoubi, M.; Jazzar, M. FA-R Effect of Different Essential Oils on the Shelf Life of Concentrated Yogurt. Annu. Res. Rev. Biol. 2019, 30, 1-9. [CrossRef]

249. Mishra, A.P.; Devkota, H.P.; Nigam, M.; Adetunji, C.O.; Srivastava, N.; Saklani, S.; Shukla, I.; Azmi, L.; Shariati, M.A.; Coutinho, H.D.M.; et al. Combination of essential oils in dairy products: A review of their functions and potential benefits. LWT 2020, 133, 110116. [CrossRef]

250. Ozkan, G.; Simsek, B.; Kuleasan, H. Antioxidant activities of Satureja cilicica essential oil in butter and in vitro. J. Food Eng. 2007, 79, 1391-1396. [CrossRef]

251. Castillo, C.; Pereira, V.; Abuelo, Á.; Hernández, J. Effect of Supplementation with Antioxidants on the Quality of Bovine Milk and Meat Production. Sci. World J. 2013, 2013, 616098. [CrossRef]

252. Castillo, C.; Hernández, J.; Valverde, I.; Pereira, V.; Sotillo, J.; Alonso, M.L.; Benedito, J.L. Plasma malonaldehyde (MDA) and total antioxidant status (TAS) during lactation in dairy cows. Res. Vet. Sci. 2006, 80, 133-139. [CrossRef] [PubMed]

253. Hyldgaard, M.; Mygind, T.; Meyer, R.L. Essential oils in food preservation: Mode of action, synergies, and interactions with food matrix components. Front. Microbiol. 2012, 3. [CrossRef] [PubMed]

254. Castro-Montoya, J.; Peiren, N.; Cone, J.W.; Zweifel, B.; Fievez, V.; De Campeneere, S. In vivo and in vitro effects of a blend of essential oils on rumen methane mitigation. Livest. Sci. 2015, 180, 134-142. [CrossRef]

255. Tóth, T.; Körmöndi, M.; Tkovács, A.; Csavajda, É.; Trombitás, M.; Tóthi, R. Effect of essential oil supplement on milk yield and composition of lactating dairy cows. Krmiva 2017, 59, 15-19. [CrossRef]

256. Katsoulos, P.D.; Karatzia, M.A.; Dovas, C.I.; Filioussis, G.; Papadopoulos, E.; Kiossis, E.; Arsenopoulos, K.; Papadopoulos, T.; Boscos, C.; Karatzias, H. Evaluation of the in-field efficacy of oregano essential oil administration on the control of neonatal diarrhea syndrome in calves. Res. Vet. Sci. 2017, 115, 478-483. [CrossRef]

257. Froehlich, K.A.; Abdelsalam, K.W.; Chase, C.; Koppien-Fox, J.; Casper, D.P. Evaluation of essential oils and prebiotics for newborn dairy calves1. J. Anim. Sci. 2017, 95, 3772-3782. [CrossRef]

258. Akbarian-Tefaghi, M.; Ghasemi, E.; Khorvash, M. Performance, rumen fermentation and blood metabolites of dairy calves fed starter mixtures supplemented with herbal plants, essential oils or monensin. J. Anim. Physiol. Anim. Nutr. 2018, 102, 630-638. [CrossRef] 